\title{
Entrevista
}

\section{ENTRE LEMBRANÇAS E HISTÓRIAS - TECENDO AS MEMÓRIAS DO DEPARTAMENTO DE ENSINO FUNDAMENTAL}

\author{
Por: Andrea da Paixão Fernandes \\ Esequiel Rodrigues de Oliveira \\ Lincoln Tavares Silva \\ Maria da Conceição de Carvalho Rosa
}

Lembrar, rememorar, mexer com as histórias que estão guardadas no fundo do baú, algumas e outras que nem tanto, foi o que moveu os (re)encontros que deram corpo a esta entrevista com professoras do Departamento de Ensino Fundamental do Instituto de Aplicação Fernando Rodrigues da Silveira, o CAp-UERJ.

Trazemos neste texto histórias e narrativas de como o Departamento foi se constituindo e de por quais rumos foram caminhando as concepções de aprender e de ensinar. Concepções essas que nos fazem, como bem lembra Olga, eternos aprendizes.

Lemos aqui as memórias de diferentes gerações que vêm contribuindo com a bonita trajetória deste Departamento que, atuando no ensino, na pesquisa e na extensão, seja na educação básica, na graduação e na pós-graduação, vem formando crianças, jovens e adultos a cada dia e vem se formando pelos caminhos trilhados e pelos diálogos tecidos.

LINCOLN: Em primeiro lugar, quero agradecer a vocês pela presença aqui. Acho que é, mais uma vez, um momento valioso na história da instituição, dar continuidade a um projeto, a uma perspectiva de trabalhar a questão da memória do CAp, através das pessoas, através dos seus trabalhadores, daqueles que constituíram, ajudaram a construir a história da instituição. E..., assim como fizemos, como o grupo da Educação Física, que falou sobre a história das olimpíadas, vocês estão aqui agora, e justamente neste momento, a gente vai estar tratando de um pedacinho fundamental, de um tempero fundamental dessa instituição que é o DEF: o Departamento de Ensino Fundamental. Até, estou sendo redundante, dizer que é fundamental o DEF. 
É... E vocês fazem parte de um grupo, esse grupo é até um pouco maior, a gente ainda vai tentar encontrar o restante do grupo, para conversar com as memórias delas. São elas..., o DEF é um Departamento essencialmente delas, mas que serve para nós todos. Eu estou aqui com uma colega, Nalu, e também tenho que explicar porque Nalu, ela mesma vai explicar porque isso também faz parte da história do Departamento, história da vida dela, história do Departamento. Quando a gente fica perguntando quem é essa Nalu? Quem é essa Nalu? Por que não chamam pelo nome... de batismo? Assim como vocês, ela também tem suas peculiaridades, suas circunstâncias próprias. Então, como diretor, eu me sinto muito feliz por estar participando desta entrevista, porque eu vou aprender muito, vou tirar algumas dúvidas e eu acho que vamos estar fazendo um registro rico para aqueles que virão, que virão logo depois de vocês, que chegam na instituição e não sabem dessa história, pelo menos fora dos registros... Quer falar, professora?

NALU: Também queria agradecer a vocês por estarem aqui hoje. E eu acredito que este é um momento interessante da gente tentar fazer essa reconstrução, né? É claro que quando a gente fala dessa parte das pessoas que viveram, essa história fica muito mais rica. Uma coisa é contar a partir das vozes, outra coisa é você contar a partir de documentação. Para mim isso é muito interessante e eu acho que é importante a gente conseguir proporcionar esses momentos. Agradeço a todas vocês por estarem aqui. E o meu nome é Maria da Conceição Carvalho. Não vou precisar contar isto aqui agora...

LINCOLN: Vai que elas mandam você contar, porque aqui elas mandam tanto quanto a gente...

NALU: Nalu ia ser meu nome. Aí minha mãe fez uma promessa, quando eu nasci, porque ela quase morreu no parto e colocou Maria da Conceição para pagar a promessa. Só que todos me chamavam de Nalu. Um dia eu cheguei na escola e começaram a me chamar de Conceição. Aí eu fui descobrir que meu nome era Maria da Conceição.

NALU: Então eu pensei, para dar início, começando pela Alice e a Olga, que estão aqui há mais tempo, iniciarem essa contação aí da história. Com a criação dos anos iniciais no CAp, em todo esse processo, que aí eu acho que vocês podem ir dando essa direção. Claro que é uma conversa. Então todo mundo pode ir emendando um ponto. Mas a gente poderia dar esse pontapé inicial. Quais são as memórias de vocês? 
ALICE: São memórias e desmemórias. Porque nos já estávamos aqui no canto, um lembrando de umas coisas, outras lembrando de outras, misturando datas, né? Porque a memória também acaba falhando, não é?

LINCOLN: Tem uma coisa que eu acho importante: quem são vocês?

OLGA: Então vamos começar por como se deu início a tudo...

ALICE: Eu nem sei se vale a pena a gente entrar em detalhes, dos anos.

LINCOLN: Você chegou aqui quando?

ALICE: Eu entrei aqui em 78, que foi o segundo ano da formação do início da educação fundamental. Quer dizer, dos anos iniciais do ensino fundamental. Por que, na verdade, 1977 começou, e eu já entrei no ano... de 77, começaram as turmas. Só houve concurso para terceira e quarta série, que na época eram séries, né? Terceira e quarta. Quando eu entrei em 78, foi quando começaram as outras séries: a primeira e a segunda. Nós ficamos algum tempo primeira, segunda, terceira e quarta. E claro que algumas pessoas foram mudando, mas em princípio..., quer dizer, ficaram..., era mais ou menos aquele mesmo padrão que havia. $E$ todo mundo entrava por concurso, que havia os vestibulinhos cursinhos particulares. Aí, as crianças apavoradas chegavam para fazer prova..., coitadas, bem novinhas, super bem novinhas, levadas pelos pais.

OLGA: Eram 60 vagas para muitos e muitos candidatos. Quase todas as crianças inscritas passavam pelos cursinhos pré-vestibulares, os "vestibulinhos", como chamavam naquela época.

LINCOLN: Naquela época, vocês participavam da banca do concurso da quinta? Já havia essa interface?

ALICE: No iniciozinho não, depois logo começamos a participar. E eu uma vez participei. A minha formação é Língua Portuguesa e me chamaram para participar da de Matemática, foi muito engraçado. Porque a banca disse, você vai tentar resolver os problemas do jeito que você conseguir. Porque a gente vai tentar ver que caminhos a gente vai aceitar, das crianças que fizeram concurso. Quais são os caminhos, os diversos caminhos que a gente vai aceitar para a resposta. E foi super interessante aquele ano. Foi muito bacana.

ESEQUIEL: E fazer uma trajetória. Porque há uma trajetória de criação. Porque o CAp começou com o ensino médio, não foi isso? 
LEILA: Veja bem, como Esequiel colocou, o colégio começou com ensino médio, depois foi para o antigo ginásio, e, até 1976, ele só tinha o antigo cientifico e o antigo ginásio. E, em 76, quando a UERJ mudou para o campus, nesse período 75 e 76, a Haddock Lobo ficou vazia. E o que fazer com a Haddock Lobo? Aí a proposta da professora Maria Lucia Weiss e do Wellington, diretores na época, foi criar o primeiro segmento, já que a Lei 5692 exigia o fundamental completo. Mas como criar? Criou-se um grupo de trabalho e aí começou apenas com terceiras e quartas séries, em 1977. 78, então, foi o primeiro ano de ingresso da primeira e da segunda. Com prova, que era o famoso Vestibulinho. Tinha curso que eles chamavam de Vestibulinho mesmo, para preparar as crianças... e era um sofrimento no dia da prova. As crianças ficavam perdidas, porque na verdade era o pai que queria que elas ingressassem, e não elas. Até tem uma passagem muito interessante, que lá pelas tantas, quase final da prova, um menino não tinha escrito absolutamente nada. E eu era a banca. Aí a dona Irna falou "Vai você lá, que é a única que tem jeito para falar com ele". Porque a banca era Cataldo..., então, pessoas que não tinham esse perfil para conversar com a criança pequena. Aí eu cheguei, sentei do lado dele e perguntei: "Por que você não fez? Você não sabe fazer?" E ele disse: "Sei tudo. Sei tudo que você quer. Quer ver?" Aí ele lia a pergunta e falava a resposta. Ele falou toda a prova corretamente. No final eu disse: "É só você escrever." Aí ele falou para mim: "Se eu escrever, eu passo né? E eu não quero passar, minha mãe que quer." Aí ele não fez. O sinal bateu, ele entregou a prova em branco, tirou zero, a mãe não deve ter entendido nada. Porque provavelmente ele seria o primeiro colocado. Então, uma posição de uma criança de 6 anos que colocou que "Quem quer é minha mãe, não sou eu". Então ele estava ali para satisfazer. Então é muito interessante, porque foi trabalhoso, mas... Bom, voltando à criação. Aí, na época, assumimos primeira e segunda séries, eu e a professora Alice, a professora Odette e a professora Rosane, que não estão mais lá. E nós assumimos. Eu assumi a primeira turma de primeira série, que inclusive era a turma do filho do Miragaya, era a turma do Roberto. Roberto Dória, que hoje é professor da escola. Uma turma assim, maravilhosa. Eles eram selecionados no vestibulinho. Então você tem grandes nomes ali. Leila Sterenberg era dessa turma e está na Globo News hoje. Tem uma outra menina que hoje, que é a Juliana... A Juliana está na BBC de Londres. Então eram pessoas altamente selecionadas. $E$ a minha experiência nessa faixa etária vinha do município do Rio de Janeiro que me deu todo o chão, eu gosto de dizer isso, para 
poder ousar o CAp. Eu tinha já uma trajetória de 10 anos no município do Rio de Janeiro. Que eu comecei em 68 e entrei efetivamente, eu participei das discussões em 77, mas não assumi turma. Só assumi em 78. E a gente tinha, na época, que seria interessante se vocês conseguirem entrevistar, não sei como ela está hoje, a professora Lúcia, Lúcia Lodi. A Lúcia foi uma pessoa fundamental na implantação do Departamento. Ela tinha uma experiência grande com o primeiro segmento no município do Rio e foi a nossa supervisora durante muito tempo. Com um trabalho muito presente na nossa vida...

LINCOLN: Eram muitas turmas?

ALICE: Eram duas turmas de cada série. Duas turmas de 30 alunos e tinha uma coisa assim: havia 60 vagas, mas não havia tantos candidatos como há hoje. Nem chegava aos pés. Eles foram aumentando muito. A quantidade de candidatos foi aumentando muito. Que no inicio eram..., assim, não chegava a 300, no início. Imagina! Aí eram 60 vagas e a proporção era bem razoável...

LINCOLN: Vocês têm ideia de onde vinha esse povo?

ALICE: Olha, a maioria era da Tijuca. A maioria era gente dos arredores. E não havia essa vaga reservada para filhos de funcionários. Então, claro que havia filhos de funcionários! A minha filha entrou, né? Mas ainda no sistema de concurso normal. Só que naquela época, eu me lembro bem, que 0 ano em que nossas filhas fizeram eram 272 inscritos. Eu me lembro direitinho esse número. E..., assim, também para julgar é difícil, né? Quando a gente fazia parte da banca era bem difícil..., muito difícil.

PATRÍCIA: $O$ aprendizado de uma criança de 6 ou 7 anos de idade.

ALICE: Fazendo vestibulinho.

PATRÍCIA: Como fazer isso? É muito difícil.

ALICE: E havia aqueles cursos, que tinham valor na sociedade...

NALU: Mas nessa época, essas crianças que chegavam aqui, na prática, já chegavam alfabetizadas, mas vão se deparar com algo mais adiante, com uma outra dificuldade para se alfabetizar.

OLGA: E tinha prova de leitura. Tinha prova.

NALU: Era todo mundo, na primeira série, já alfabetizado.

OLGA: Era uma interpretação de texto e uma redação. Então, imagina. 
PATRÍCIA: E que tipo de texto era feito?

OLGA: Ah! Eram textos bons.

ALICE: Mas o que acontece? Tinha um texto que era de interpretação, com algumas questões e, claro, não eram questões tão fáceis.

NALU: Porque tinha que eliminar, né?

ALICE: Porque tinha que eliminar. E a parte de redação, de produção escrita, era atrelada ao texto que havia na prova.

OLGA: O de nossas filhas foi um texto falando da história de Clarinha, que eu não me lembro quem era a autora, agora, nessa prova. Mas nós nos conhecemos através de nossas filhas, que eram da mesma turma e marcaram um encontro. Elas marcaram um encontro para nós nos conhecermos e ficarmos amigas, e deu tudo certo, né? (Risos)

NALU: Porque você ainda não trabalhava aqui, né? Você veio depois...

OLGA: Eu vim quase 10 anos depois, eu vim em 1985. E também não fizeram cursinho. A minha filha veio de uma escola municipal. Ela era minha aluna de uma escola pública, faço questão de dizer, municipal, no Alto da Boa Vista. Aquela escolinha linda e maravilhosa, ali onde você entra para o Açude da Solidão. A escola é considerada patrimônio público. Linda a escola, uma alfabetização como era naqueles moldes, mas ela entrou também. A Sabrina veio de onde, Alice?

ALICE: A minha era de escola particular

OLGA: Ah, era de escola particular. Mas ambas entraram, quero dizer, sem cursinho. Porque normalmente tinha que fazer cursinho.

LINCOLN: O que isso provocava em vocês? Essa coisa de ter um funil já, como essa questão do Vestibulinho, como chamavam. Para vocês, para o Departamento, como é que isso circulava? ALICE: Olha, eu acho que isso aí foi se agravando também. No início, como eu disse, eram menos candidatos, então nem havia essa questão do vestibulinho. Isso foi surgindo. Havia muito mais para a quinta série, para o concurso de quinta, do que para o concurso de primeira.

ESEQUIEL: Se você me permite, Leila, você está usando a expressão "Departamento", mas antes não era Departamento, que nome tinha?

LEILA: Era Seção Didática. Só virou Departamento em 1986. E o primeiro segmento tinha um problema muito sério, na época. Não sei se alguém já tocou nisso. Nós tínhamos que trabalhar 
25 horas semanais. E o contrato com a UERJ era de 20 horas. Então a gente recebia hora extra. Um mês recebia, no outro não recebia... Nós só passamos a 40 horas, também, em 1986, quando se criou o Departamento e todos os professores que integravam a Seção Didática foram para o Departamento de Ensino Fundamental. Passaram para 40 horas automaticamente, e aí se resolveu o problema das horas extras, que ora a gente tinha, ora a gente não tinha. E aí, desde 86, já é Departamento, até agora. Não sei também se alguém já comentou, colocou, e seria interessante entrevistá-lo, também não sei como ele está hoje, é o prof. Wellington. Foi o grande... ele não era formado em Pedagogia, ele era formado em Língua Portuguesa, mas foi um grande supervisor durante muitos anos na escola. Ele hoje mora em Teresópolis e não sei como é que está. Mas foi um período assim muito grande de ousadias no colégio, como um todo, porque o Wellington estava à frente o tempo todo. As propostas, as nossas famosas quintas-feiras, em que o colégio todo se reunia e se reunia com ele a princípio. E ele sempre tinha propostas inovadoras para o colégio.

LINCOLN: Deixa eu fazer uma outra pergunta: O impacto da mudança de um vestibulinho para um sistema de sorteio era sentido por vocês? Como é que ficou a natureza do trabalho do DEF com essa mudança?

LEILA: Quando se começou a mexer... Que o vestibulinho deixava a gente muito preocupada no primeiro segmento. E quando se discutiu pelo sorteio, foi uma grita não só interna como externa. Externa como momento em que o CAp fazia parte dos jornais, quase que diariamente. Porque os pais diziam que a qualidade ia mudar... Foi a reunião de pais, quando a direção na época convocou uma reunião de pais, a mais concorrida que houve na história da escola. Porque eles foram, em peso, para tentar pôr abaixo a ideia do sorteio. Fora isso, tinha toda uma pressão dos vestibulinhos. Acabava a questão financeira com os vestibulinhos.

LINCOLN: A galinha dos ovos de ouro.

LEILA: Era. Vinham vários diretores de escolas externas na direção, pedindo que permanecesse o vestibulinho e, internamente também. Os próprios colegas da quinta série em diante faziam uma pressão muito grande, porque a qualidade ia cair. E eles compraram a ideia que os pais colocaram, que a qualidade ia cair. Era o discurso. E nós tentávamos, a todo custo, mostrar que era uma forma de manter a qualidade também, que o desafio seria maior, sem dúvida. A gente tinha crianças altamente selecionadas. Então, o desafio de pegar a criança assim que chegava 
sem saber segurar num lápis, pegar criança pobre das comunidades no entorno do colégio, era um grande desafio.

ESEQUIEL: Isso mil novecentos e...

LEILA: 1987. Foi a primeira turma que entrou. Entrou como? Manteve-se ainda o ingresso na primeira série. Uma turma na primeira série ingressou por concurso ainda, mas um concurso diferente. Foi feita uma prova de aptidão e eles passaram por sorteio também. Então se compôs essa turma. E duas turmas já da classe de alfabetização. E aí foi um momento também muito bonito do colégio de se estudar. O Departamento, aí já era Departamento, criou um grupo de trabalho de psicopedagogia para discutir e trabalhar com a questão da implantação da classe. Então foi um tempo de muito estudo. Fazia parte a professora Alice, eu fazia parte, porque eu sempre pegava as séries iniciais. $E$ um momento muito bonito. A fonoaudiologia estava presente que depois acabou também no colégio. Então é muito estudo. E isso passou a ser..., nós passamos a dar cursos. Foi aí que começou a questão dos cursos, porque o município do Rio de janeiro também estava em processo de mudança... e a gente saía muito para dar curso. Éramos contratadas por secretarias de educação para levar a experiência da nossa CA para fora do colégio.

OLGA: Então, a partir de 1987, quando as crianças entraram por sorteio publico, foi uma época de redemocratização mesmo. De se pensar uma escola diferente. Nós, do ensino fundamental, tivemos um papel nessa luta. Porque nós queríamos alfabetizar. Não queríamos também as crianças entrando já alfabetizadas. Tivemos uma pequena participação nisso. Aí, com essa entrada de crianças não alfabetizadas, nós tínhamos que pensar, então, no processo de alfabetização. Aí estavam chegando pesquisas de Emília Ferreiro ao Brasil. Fizemos cursos. Alice e eu pagamos um curso à noite no Leblon. Saíamos dez horas da noite do Leblon. E para estudar a teoria de Emília Ferreiro. Depois tínhamos, ao mesmo tempo, na própria escola, uns encontros com a Professora Maria Lúcia Weiss, que era do Centro de Humanidades, cujo neto está aí agora.

LINCOLN: Ela era professora do Departamento?

ALICE: Não, não. Ela tinha sido diretora do colégio e depois ela foi pro Centro de Educação e Humanidades e ela, junto com a Ambrosina, que era orientadora educacional e Tereza também, as duas e mais algumas estagiárias que participavam dessa discussão. O que a gente fazia aí era uma discussão mesmo. Quero dizer, eu acho que a gente teve uma participação grande e 
enorme, principalmente porque nós lutamos para o ingresso por sorteio. Isso aí foi uma luta muito grande.

NALU: Uma luta política, mais que pedagógica.

ALICE: E teve muita resistência sobre isso. De gente do próprio ensino fundamental, das séries fundamentais.

NALU: Que é uma primeira elite...

ALICE: E de gente de série mais avançada. Houve muita, mas muita resistência.

Olga: É que esse pessoal das séries mais avançadas, eu acho que não entendia como é que essas crianças, que iam entrar por sorteio, iam chegar lá na quinta série. Que era tudo série antigamente. Então foi uma luta. Mas eu acho que isso deu um empurrão na gente. Para mudar toda a nossa prática. Nós começamos a repensar muito: o que é se alfabetizar? O que é o alfabetizar? Invertemos a ordem. Ao invés de estudar o "como se ensina", passamos a estudar o "como se aprende". Como é que se aprende? E aí, muda tudo. Muda o foco. E começamos, também, a fazer com a professora Maria Lúcia Weiss, a estudar Piaget na própria escola. Ficávamos um dia à tarde por semana, e tínhamos um curso com ela. E fomos mudando. Estudamos Vigotsky. E fomos conversando muito. No início, Alice, no primeiro ano, ainda tivemos um processo de alfabetização meio capenga, que nós mesmos na época fomos sentindo... fomos estudando, avançando.

ESEQUIEL: Por falar em concepção pedagógica, você falou em um Departamento de Ensino Fundamental, antes Seção Didática, mas a ideia era a mesma. Mas tem uma característica hoje, que quando eu entrei já acontecia, que é o trabalho do Departamento de Educação Física e Artes, também com outro nome na época, constituindo um trabalho só. A proposta pedagógica do ensino fundamental, das séries iniciais é articulando Artes com Educação Física. Isso foi desde o começo? Isso foi compartilhado? Como isso se deu? Porque... só completando a pergunta, a partir da quinta série do ensino fundamental cada Departamento atua... a articulação se dá no espaço de Conselho Departamental, das reuniões pedagógicas e tal. Já o Departamento de Ensino Fundamental dá conta da formação integral do estudante, mas há a parceria com essas outras disciplinas. Você pode falar um pouco mais sobre isso?

LEILA: Olha só, quando se iniciou toda discussão que o primeiro segmento teria essa gradação, isso sempre aconteceu, de ter um dia integral, dois dias integral, a gente precisava fazer essa 
parceria com as outras disciplinas. E aí foi um encontro muito interessante. Nós tínhamos inclusive as... inicialmente, as aulas eram no mesmo horário e nós tínhamos que acompanhar os alunos nas atividades que chamavam, as outras disciplinas, nós tínhamos que acompanhar. Fora isso... dentro, o professor Welligton, aí eu vou voltar a ele, às quintas-feiras, tinha um espaço reservado para o primeiro segmento se encontrar com as seções didáticas. Cada quinta-feira era uma para elaborar um trabalho integral... até o nono ano, hoje nono ano, na época oitava série. E aí nós tínhamos, na equipe de coordenação de disciplina, exemplo: Língua Portuguesa - tinha uma pessoa formada em Língua Portuguesa, que compunha o grupo de coordenadores de disciplina. Que aí a gente tinha noção da Língua Portuguesa até o nono ano. E eles diziam para nós o que era necessário ser trabalhado. Fazia isso com Matemática, Língua Portuguesa, Ciências, História e Geografia. Então tinha uma linha que... e isso se perdeu. No momento em que passaram... quando se veio para o campus, e as reuniões de quinta-feira se diluíram, a gente deixou de ter esse espaço privilegiado. Porque aí as reuniões aconteciam no próprio primeiro segmento, o coordenador das primeiras disciplinas estava lá dentro com a gente. Então foi um trabalho realmente em conjunto. $E$ isso com a divisão do Departamento, que aí cada um ficou na sua, como se diz na gíria, se perdeu... não se perdeu nas disciplinas que permaneceram compondo a grade no primeiro segmento. A proximidade, principalmente com Artes e Educação Física, até hoje é muito grande. A gente planeja atividade, por exemplo, quando eu fazia Paraty, eu sentava com Artes e com Educação Física para pensar o trabalho que seria desenvolvido em Paraty. Aí se fez grandes trabalhos. A professora Mônica chegou a criar livros com eles... então é um trabalho até hoje compartilhado com as disciplinas do horário da tarde deles. As coisas são trabalhadas a partir do que a gente está trabalhando. Na alfabetização, por exemplo, o Raul deve ter falado sobre isso, ele trabalhava as questões das letras, com o corpo... Então isso tudo era integrado e continua sendo. Agora, o restante se perdeu. O que é uma pena, porque Matemática..., principalmente Matemática, Português nem tanto, mas Matemática se distanciou muito de nós e era fundamental. Por isso eles ficam tão perdidos quando eles chegam ao sexto ano. E em Matemática, principalmente, e aí eu estou falando do seu (Esequiel) Departamento, porque nós nos perdemos nesse caminho.

NALU: Um processo de aprendizagem sem igual.

OLGA: Um processo sem igual, claro. E fomos vendo que, como a gente podia reverter tudo 
que a gente já tinha aprendido, principalmente nos cursos de formação inicial.

LEILA: Inclusive, quando o Departamento foi criado, lá pelos anos setenta, foi muito interessante, porque se colocou que, para atuar no primeiro segmento, o professor, que ainda não era estatutário, o professor tem que ter um curso superior. Na área da licenciatura. Ele tem que ter a especialização dele nas séries iniciais. Então isso foi uma coisa que foi diferente de tudo. Hoje alguns CAps têm, mas na época só o nosso teve o Colégio de Aplicação dentro da carreira docente. Que, quando virou Departamento, nós estávamos na carreira docente. Houve até uma discussão, quando virou Departamento, se os professores, se era necessário criar o Departamento de Ensino Fundamental, ou se cada um ficaria pela formação dos outros Departamentos, atuando no Ensino Fundamental. E aí começou a surgir, até por conta da professora Ângela, que já faleceu infelizmente. A Ângela era psicóloga, e onde vai colocar a psicóloga? Então aí a gente optou por permanecer. Foi na época em que a professora Marcia Moraes migrou do nosso Departamento para o DLL (Departamento de Línguas e Literaturas). E aí tinha que migrar. Que inicialmente a Marcia Moraes era do DEF, mas nesse momento, ela acabou migrando pro DLL. Então foi um movimento, foi um período para o colégio muito rico . $\mathrm{O}$ período de 86 , de grandes mudanças.

LINCOLN: Acompanhou o contexto da universidade, né? Que a universidade estava em ebulição também nesse momento... pelo regime de carreiras.

LEILA: E aí tem um problema, né? Como nós ficamos diferentes de todos os CAps... E eu acho que isso é até hoje. Os outros, tem até o da UFRJ, eles têm mestrado e doutorado, mas eles são professores de ensino médio e fundamental. Então o nosso CAp é diferente dos outros. $E$ isso, para a qualidade, também é importantíssimo. Muito importante. As pesquisas girarem em torno desse olhar nosso para as séries iniciais, que é um olhar diferente, quer queira, quer não. Nós não somos diferentes, o nosso olhar é que é diferente, para aquelas crianças, para aquela faixa etária. Então isso é muito importante. Vamos lá...eu não sei se estou me perdendo aí, eu só estou conversando.

ESEQUIEL: Nós temos...

LINCOLN: Você acha que isso alimentou o viés extensionista? Porque são Departamentos que têm uma natureza extensionista... 
LEILA: Exatamente. E aí nós começamos a entrar pelo viés da extensão. Por exemplo, InterCAp nasceu um pouco depois, mas daí, dessa necessidade. Como nasceu o InterCAp? O colégio foi procurado pela equipe de Medicina, que eles faziam um Internato Rural em atividade que havia uma demanda muito grande na área de educação, que se pensasse um projeto para atender os professores. Aí nós começamos. A professora Marcia, que coordenava inicialmente o InterCAp, sentou com um grupo que estava interessado, que antigamente nós não tínhamos carga para a extensão. Nós íamos... era o "Exército de Brancaleone" que a gente comentava.

LINCOLN: Graciosamente.

LEILA: Saíamos para o interior do estado para dar curso. Tanto que hoje o Internato Rural não existe mais, da forma como existia, e nós crescemos. O InterCAp está aí até hoje. E a extensão no nosso Departamento, porque aí, como nós éramos chamados a dar curso, aí se criou uma série de projetos. A Olga criou um projeto... Aí a coisa foi crescendo e hoje o Departamento tem uma inserção grande na extensão. Não só o Departamento, mas o colégio, como um todo. Mas a característica do DEF é muito mais extensionista.

LINCOLN: Isso alimentou também uma formação no campo de pesquisa.

LEILA: Sim.

LINCOLN: Que você fala que estudaram muito.

LEILA: É que aí que você fazia dialogar a pesquisa com a extensão. E aí as pessoas começaram um investimento e a entrada do colégio também na pesquisa, pela capacitação do pessoal. Isso foi ampliando.

ALICE: Também quando Maria Lúcia Weiss era a diretora, uma questão para a qual ela chamou muito a atenção da gente foi que o nosso papel era de formação de professores. De receber estagiário. Ela batia muito nessa tecla. Muito importante isso, porque o Colégio de Aplicação existe por causa disso, para isso, né? Você receber estagiário.

LINCOLN: Algumas pessoas esquecem isso.

ALICE: Novas metodologias, então, tudo isso. Na época, a direção, eu acho que era a Cristina Gurgel. Primeiro a Cristina Ferreira, depois a Gurgel, elas também voltaram a bater nessa tecla. Porque cada vez que havia essa resistência, elas entravam e faziam lembrar isso.

NALU: Quer dizer que vocês tinham o apoio da direção?

ALICE: Total. Total apoio da direção. O Lincoln perguntou de onde a gente veio, eu tinha anos 
de município, inclusive de alfabetizadora, basicamente. Eu era alfabetizadora no município. Assim, o que a Stela já falou de você pensar muito em como fazer todas as crianças aprenderem, eu trabalhei em Vigário Geral, um lugar paupérrimo, trabalhei na favela de Ramos. Quando eu fui trabalhar no Leblon, ainda havia favela do Pinto, naqueles idos anos. Então peguei crianças de favelas durante muito tempo e uma coisa que sempre me angustiou, de vida de professora, foi como fazer todo mundo aprender. Isso aí, quando a Olga comentou também, quando a gente começou a reformular a maneira de trabalhar, foi pensando também, repensando algo que fosse melhor, porque, mesmo você trabalhando com as outras metodologias, mas é lógico que você tem uma intuição. Quando você se incomoda por a criança não aprender, você faz algumas coisas intuitivamente. Eu me lembro da Telma falando da gente depois de anos que eu vim a reencontrá-la, quando ela fez um trabalho para o MEC. Ela falou assim: "Vocês, né? A prática foi bem na frente da teoria. Vocês tiveram um percurso único, diverso. "Vocês tiveram...", esse grupo que começou o trabalho, "vocês tiveram um percurso completamente diferente do que a gente vê normalmente. A prática de vocês estava lá na frente e a teoria cá atrás". Quer dizer, a gente teve que estudar muito para conseguir chegar perto.

NALU: Eu lembro que vocês visitaram o Centro Comunitário... o Centro de Atividades Comunitárias em São João de Meriti, o CAC. Porque a gente tinha esse trabalho já nessa linha e vocês foram lá conhecer. E era um trabalho pobre. Na época, era o único trabalho nessa perspectiva com criança pobre. Porque onde tinha eram instituições particulares.

LINCOLN: Isso foi em que ano?

NALU: Acho que vocês foram lá em 1989...

ALICE: Eu já tinha ido a São Paulo.

NALU: Em São Paulo já tinha as referências que o próprio CAC foi buscar, na Escola da Vila. Dali que a gente... depois no México...

ALICE: Assim, a UERJ que bancou essa minha ida. A Lúcia Lodi, que era na época supervisora e a Sonia, que era de Fonoaudiologia.

OLGA: A professora Lúcia Lodi.

LINCOLN: Sonia... Fonoaudióloga... isso! Sonia Zampronha.

ALICE: Nós fomos a São Paulo para ouvir o trabalho da Escola da Vila. Havia um encontro lá, enorme, e a Telma que falou, que já não estava mais na Escola da Vila, mas ela falou lá do tra- 
balho dela também. Nós ficamos muito apegadas a ela também. Nós trouxemos para o CAp alguns cursos da Escola da Vila também. Isso nós tivemos um movimento enorme.

NALU: Eu me lembro dessa fase...

ALICE: Nós estivemos junto com o pessoal do município. A gente tinha um entrosamento. Nós organizamos encontros que foram aqui na escola, né? À noite, né?

OLGA: Tivemos o primeiro curso à noite, aqui nessa escola...

ALICE: O nosso curso, nós demos. Mas, eu estou falando, a gente trouxe tudo para cá.

NALU: Eu lembro que a Sonia Barreiros, a gente ficava sabendo de algumas coisas. Como a gente estava no CAC e tinha as mesmas relações, eu ficava sabendo. Aí, eu lembro da Sonia falando: "Estou indo aí para dar um curso."

ALICE: E aquela de Matemática, que não me lembro, Maria Tereza eu acho...

NALU: É Maria Tereza, da Matemática.

OLGA: Aí começamos a mudar radicalmente o trabalho e a mudar o ambiente da sala de aula. Esse ambiente aqui, que vocês estão vendo, nós não tínhamos um ambiente assim, tão letrado. E passamos a mudar a nossa postura, frente à leitura e à escrita. O que acontece até hoje. Que é uma prática nossa, em todas as turmas, do professor fazer questão de ler para seus alunos diariamente. Então isso veio mudando todo o trabalho. Porque, se você lê diariamente para os alunos, eles também vão começar a ter outras respostas, outras escritas, outras dúvidas, outras perguntas... E a gente dizia assim! A gente falava muito isso no curso de professores, e começamos a ser chamadas pelas secretarias de educação do município e do estado, a gente ainda com pouca experiência, mas a gente já dava cursos, a gente já trocava com outros professores. E a gente também foi aprendendo com eles. Porque era uma troca. A gente estava muito no início. A gente fez um seminário, e éramos chamadas de "as musas da alfabetização"... Raul vai lembrar bem disso. Raul falava isso.

STELLA: Era de uma forma crítica. Era como se fosse assim meio que um deboche. Eu faço questão de falar isso porque havia uma divisão no Departamento, de concepção. E quando eu cheguei, eu percebi isso claramente.

LINCOLN: E quando foi que você chegou?

STELLA: A gente estava em dúvida aqui. Eu cheguei aqui em torno de 1994, 1993. Eu acho que foi 93. Mas então eu percebia isso. Que havia uma divisão assim, muito grande. No próprio 
Departamento. E elas eram chamadas de "musas da alfabetização" porque era uma dúvida em relação ao processo: Como é que vai ser? Como é que esse aluno vai escrever? Será que ele vai escrever corretamente? Não vai escrever corretamente? O que é melhor, né? O que a gente vai priorizar aí nesse processo? Escrever corretamente ou pensar? Refletir sobre o levar em consideração o tempo que a criança precisa para aprender, para se apropriar do conhecimento. Então, quando eu chego, já encontro esse embate.

ALICE: Inclusive, um outro embate quando a gente teve nessa época, foi porque a gente resolveu, a partir de um curso que nós coordenamos pelo CEPUERJ, nós resolvemos abrir para visita de professores do município. Abrir a nossa sala de aula para visita de professores do município. E muita gente não queria que isso acontecesse.

LINCOLN: Me falem das rodas. Como é a importância disso para essa história? Porque quando vocês falam nessa diferença, tem um trabalho pedagógico.

LEILA: A roda... eu comecei... Aí tem a ver com a história do clube. Eu comecei... eu tinha uma turma que eu costumo dizer, não que eu.... Eu tenho um maior carinho por todos eles, mas essa turma foi muito especial. E eu digo que é minha turma preferida. Eu tenho até uma pasta que é "Turma preferida". Eu peguei essa turma na primeira série, só não peguei na segunda. Levei essa turma até o fim. Foi a turma que criou o clube. Eles começaram, havia um menino super esperto, e aí, no momento em que eu contava história... eu sempre fui, eu fui de uma época no município do Rio de Janeiro que tinha um setor muito importante, que infelizmente a ditadura militar acabou com ele. Era um setor de bibliotecas e auditório. Onde se trabalhava muito o contar história para criança, isso o município perdeu. Porque, na época da ditadura, o que aconteceu? Fecharam as bibliotecas das escolas do município e terminaram com bibliotecas e auditórios. Era perigoso ler. Então eu tinha essa formação com o município. Aí eu levei pro CAp. Por isso que eu digo que o município é o meu chão para ousar no CAp. Aí eu contava muita história para eles. Aí esse menino, certa vez, falou para mim: "mas a gente ouvia história, que você diz que lia, de liberdade. A gente ouvia história com grade na janela, a gente está preso!" E eu falei: "É verdade. Então nós vamos passar a contar história embaixo da mangueira". Tinha uma grande mangueira na Haddock Lobo, onde você lembra... logo na entrada. E a gente ficava ali contando história, discutindo. Aí que começaram as rodas. Discutindo e aí o Departamento 
começou... Na época eu era muito criticada. Eu cheguei a ouvir de uma colega que eu saía da sala porque eu não tinha o que fazer na sala.

LINCOLN: Deixa eu fazer um parêntese aí. As meninas, na fala delas, colocaram muito a questão de que o Departamento não era essa coisa coesa, existiam concepções pedagógicas diferenciadas. Que horas se alinhavam, que horas se afastavam, mas que o Departamento, apesar de tudo isso, cresceu. E superou até algumas divergências...

LEILA: E isso era umas das divergências... Mas tinha essa questão, sim. Havia pessoas... qualquer mudança é difícil. Você não muda um grupo inteiro de uma hora para outra. Mas felizmente o grupo que estava tentando mudanças era maior que o grupo que queria a concepção mais antiga. Não estou falando da qualidade dos professores, porque eles eram excelentes professores. Mas havia isso, eu, na época, sofri muito com o Clube. Porque eu não tinha o que fazer, e eu, já naquela época, achava que sair dos muros da escola era mais interessante. Então eu ia fazer feira com as crianças, com essa turma. Eu ia domingo... eu fui uma vez num domingo para o Campo de São Cristóvão com eles. Quando eu estava trabalhando a questão do Nordeste, das regiões do Brasil. Mas na época eu não tinha o que fazer, eu tinha é muito mais. Então, na época, as pessoas tinham medo de sair... Hoje, eu fico muito feliz de ver que determinadas coisas que eu fui super criticada, estão presentes no Departamento. E aí isso é muito legal.

OLGA: Imagina nós? Aprendizes também, né? Que éramos..., somos ainda, mas que éramos em muito maior grau recebendo professores do município. E começamos a fazer tanto sucesso, o nosso trabalho, não nós! Começamos a ser chamadas para dar os cursos pelas secretarias de educação do estado e do município. E fomos rodando aqui. No Estado do Rio de Janeiro todo. Aí, vêm outras pessoas, porque tinha a Stella, a Cristina, outras pessoas também começaram a fazer parte.

STELLA: Mas tem um antes disso. Na época dos CIEP. Que Alice, quando conheci Alice, Alice foi minha professora.

LINCOLN: Era isso que eu ia perguntar, de onde vocês vieram?

STELLA: Eu era professora da rede municipal de ensino e fui ser coordenadora num CIEP localizado na Maré e, nós naquela época, também no município do Rio de Janeiro, estávamos nos questionando sobre as metodologias, as concepções de alfabetização, justamente porque as 
classe populares estavam tendo acesso às escolas públicas, enfim. E aí nós tínhamos que fazer um curso de formação e a Alice, na UERJ, foi a minha formadora. E quando eu cheguei lá como coordenadora de alfabetização desse CIEP, uma das coisas, assim, que eu me lembro até hoje, a expressão da Alice, que eu tinha uma amiga. Nós éramos muito questionadoras. Então a metodologia do método era o psicolinguístico. E aí, eu ficava sempre pensando como coordenadora de alfabetização desse CIEP naquela dúvida, né? Que nunca quer calar, que até hoje não cala quando a gente se encontra no mesmo lugar de formadora diante de professores que estão no início do trabalho. E aí é aquela dúvida: "Meu Deus as crianças, como fazer? O que fazer com essas crianças?" Tem um método que está sendo imposto, mas as crianças não estão aprendendo. Aí quando a gente levava essas questões para a Alice, Alice não tinha muita resistência. E isso deixava a gente... A falta de... Hoje eu consigo, mais distante, pensar desse modo. Naquela época não. Eu falava assim: "Caramba!" Ela não criava nenhum tipo de... ela nos ouvia. Ela era uma formadora que eu posso considerar uma ouvinte. E ela é. Ela trazia dúvidas também. Ela deixava no ar que ela também tinha dúvidas sobre aquelas metodologias e eu vim reencontrar a Alice aqui depois, quando eu passei, quando eu entrei aqui no colégio como efetiva. Primeiro eu fui quatro anos contratada do Colégio de Aplicação. Quatro anos seguidos. Aí eu encontro a Alice, e aí eu falo "nossa que bom". Porque eu gostei do modo o qual ela formava. Um modo que não criava assim: "não tem que ser assim, tem que ser assado, não tem que fazer isso". Era um diálogo.

NALU: Sem imposição...

STELLA: Que me deixava um pouco frustrada porque eu ia para lá prontamente, para criar um embate. Mas ela não entrava na minha. Ao mesmo tempo, ela também refletia junto. Então ela foi minha primeira formadora. Assim, muito tempo depois foi que eu fui ter essa consciência. Uma formadora diferenciada.

OLGA: De tantos cursos que a gente começou a dar aqui e ali, Alice teve a grande ideia de criar mesmo um projeto de extensão. E que começou no complexo do Borel. Tinha uma escola de educação infantil embaixo e uma creche lá em cima, no morro, que algumas vezes a gente subiu de carro da comunidade, porque não podíamos subir nos nossos carros. E ficamos quanto tempo no Borel, Alice? Eu não lembro essas datas, estão fugindo...

ALICE: Eu acho que foram uns dois anos. 
OLGA: Foram dois anos no Borel e daí nós partimos para o Instituto de Educação. Aí éramos eu e Stela, eu e Nalu. Estivemos lá por uns quatro ou cinco anos. Margarida aqui da escola participou desses cursos. Quem deve lembrar bem, ela era aluna, hoje é professora aqui no CAp.

LINCOLN: Vocês enxergam isso como uma função importante desse Departamento? Essa troca com a rede, como isso refletia nas funções do Departamento?

OLGA: Era confuso, porque tinha um grupo a favor e o outro grupo contra. Assim, contra, que não acreditava muito. Mas a gente ia se fortalecendo, porque eles não queriam.

LINCOLN: Como é que isso se reconjuntava dentro desse Departamento, onde existam visões plurais? Diferenciadas. Quer dizer, como é que juntava essa prática pedagógica do desafio da alfabetização, um desafio renovado, com a continuidade desse processo? Nós estamos falando do primeiro, segundo terceiro e quarto ano do primeiro grau. Foi assim que começou. Depois CA...

OLGA: Eram sempre as mesmas que pegavam as primeiras séries

NALU: Aí acabou dividindo em séries

LINCOLN: Como é que isso ganha corpo?

OLGA: Cada professora tinha a sua liberdade de cátedra.

LINCOLN: Vocês se reuniam? Discutiam?

OLGA: Altas brigas. Tinha aquele momento de sair da sala, bater porta... terrível!

ALICE: Uma das soluções foi a gente...

NALU: Uma das coisas boas nessa época, que eu acho, é que as coisas eram ditas. Porque os dois grupos eram muito sérios, tanto o grupo mais tradicional, quanto o pessoal que estava trazendo essa nova visão. Eram super profissionais, sérios, e essas brigas essas discussões, esses embates aconteciam de fato...abertamente.

ALICE: Era uma discussão pedagógica.

NALU: Era uma discussão pedagógica.

STELLA: Era uma briga de concepção. Mas eram respeitosas. Na relação pessoal.

OLGA: Até porque as outras haviam sido professoras das nossas filhas, né? Era uma mistura...

NALU: E isso é legal marcar, por causa disso, eram duas concepções de profissionais super sérios, super comprometidos e competentes. Então isso era muito legal.

ALICE: Uma das soluções foi a gente pegar a CA e continuar com a primeira série... 
OLGA: Aí nasceu o BUN, o Bloco Único. Que ficou zombeteiramente chamado de BUN.

ALICE: E, como a Olga falou, sempre as mesmas. Como até hoje costumamos ser.

STELLA: Regina, Alice e Olga. E a Heloisa também. A Heloisa ficou pouco tempo. A Marcia chegou a pegar pouco tempo também.

OLGA: Nós seguíamos com a turma. E acreditamos tanto nisso, que isso virou a regra até hoje. Não existe reprovação. Retenção, porque reprovação é uma palavra horrível. Não existe retenção no primeiro ano, até hoje. Eu acho que isso foi um ganho enorme para a nossa escola. Enorme. Nós acreditamos no processo. Acreditamos que a criança do primeiro, que ainda não conseguiu estar plenamente alfabetizada, ela tem condições de ir para o segundo ano.

ESEQUIEL: Quando eu entrei em 1986, o professor Wellington já não estava mais...

LEILA: Não. Ele se aposentou depois, quando a Maria Lucia terminou a gestão, ele estava como vice-diretor, acumulando com a supervisão pedagógica, porque ninguém quis que ele se afastasse. Aí é uma pena, que eu considero uma pena, lamentável o que aconteceu com os arquivos do antigo SOP, que eram arquivos riquíssimos. Na época em que o colégio foi trazido para o campus, de uma forma bastante atropelada, se queimou todo arquivo do SOP, porque era "papel velho demais". Foi assim que a direção na época considerou. E ai nós perdemos todo esse acervo. Da memória

LEILA: Porque faz falta. Faz muita falta.

\section{ESEQUIEL: Sim.}

LEILA: E aí não pode ficar. Como eu tinha essa prática, eu vivia atrás de Maria Ignez, vivia atrás dos professores. Então, como eu ultimamente sempre pegava o quinto ano, eu conseguia fazer essa ponte... E eu estou começando a me emocionar. Não quero, não posso.

LINCOLN: Aí eu vou fazer uma pergunta que é para além do DEF, que é uma pergunta para todos que vão ler este processo, que vão ter este registro, que até vão ver este registro e que até vão ver vocês. O que diferencia isso daquilo que ficou famigeradamente conhecido como a aprovação automática?

ALICE: Eu ia tocar nesse assunto. Eu lembrei exatamente disso. Porque assim, até hoje você vê a maioria dos professores da rede pública do Brasil inteiro reclamar da aprovação automática. Isso aí é uma outra questão. Essa é a seguinte questão: se você reclama da aprovação automática, eu acho que você está se dando... você está reconhecendo a sua incapacidade. Eu acho 
isso. Porque a questão da aprovação automática é uma questão de concepção também. Se você vê... Você tem que enxergar aquilo que o aluno aprendeu. Conseguiu aprender e sempre está vendo o progresso dele. Se você não consegue enxergar isso, é claro que a aprovação automática vai ser um desastre. Se a sua concepção é de que chegou num ponto tal, e ele tem que ter aprendido tais e tais coisas, apesar dele ter evoluído muito, ele tem que ter aprendido tais e tais coisas para você aprovar. E é uma outra questão, como existem milhares de pesquisas mostrando que, apesar da criança ser reprovada, isso não garante que ela vá piorar. Vai melhorar porque foi reprovada. Tem essas questões. Mas é uma coisa difícil. É muito difícil. Você não... Tudo bem que, no início, não é tão difícil. Mas quando se chega no segundo e terceiro ano, já começa a complicar um pouco.

OLGA: Alice, eu acho que também tem o outro problema, do professor que já que tem a aprovação automática que não é a regra, mas que existe... ah, então deixa o barco correr. Também não se preocupa em fazer o aluno aprender. Então eu acho que nesse espaço maior de município, de estado, eu acho que a gente tem sim professores que não se preocupam, na verdade, com essa aprendizagem. "Ah! Se tem a aprovação automática, então deixa para lá. Aprendeu, aprendeu. Não aprendeu, aprendesse". Não há esse comprometimento. Agora deixa eu voltar um pouquinho, ao que você perguntou sobre a nossa vida anterior. Também fui professora alfabetizadora, quase todos os anos da minha vida no município, por escolha. Trabalhei com todos os métodos possíveis e imaginários. Fiz pata casar com pato para ensinar o "o", gata casar com gato, aliás, não fiz o casamento porque eu achava já ridículo. Mas usei a estratégia. Agora, fazer o casamento como se fazia naquela época, eu me recusei um pouco. Salvei um pouco. Mas enfim, eu acho.

STELLA: Tinha o casamento quem era o melhor, porque tinha a festa.

OLGA: Que era o melhor de tudo. Festa, brigadeiro. Mas eu fico pensando assim, todas as escolas onde eu chegava, foram pouquíssimas. Trabalhei em quatro escolas no município do Rio de Janeiro durante 25 anos. Ficava bastante tempo na minha primeira escola. Fiquei 15 anos no Alto da Boa vista, nesse lugar maravilhoso eterno. E quando eu cheguei lá e a diretora perguntou: "Qual a série que você quer pegar?" E Eu falei: "Primeira serie". A diretora me olhou e falou assim: "Não acredito." E eu falei: "Por quê?" "Porque ninguém chega aqui falando que quer primeira série. Todo mundo só quer terceira série, quarta série". Mas eu falei: "Não, mas eu 
quero, faço questão". Aí fiquei com primeira série. E fico pensando em como eu fazia os meus alunos aprenderem, apesar de casar gato com gata, pato com pata... Apesar de trabalhar com método fônico. Não era abelhinha, mas era outro parecido, horroroso. Que eu ficava treinando no espelho, sem mentira nenhuma, a noite toda como é que eu vou fazer /pu/ /pu/ /pu/. Não podia fazer Pá porque era $\mathrm{P}$ com $\mathrm{A}$, não podia fazer PI porque era $\mathrm{P}$ com I. Minhas irmãs, professoras também, e eu nos reuníamos e ficávamos rindo, e uma tentando mostrar para a outra como fazer isso. Ainda teve a maldita coisa do "tia". Ficamos treinando em casa: "O que a gente diz para nossos alunos? Que agora a gente é tia?" Um horror! Hoje a gente desconstrói tudo. Mas, naquela época... 1964, eu me formei naquele ano bom. Interessante. E aí, como é que eu conseguia alfabetizar? Eu acho que eu fiz muita insurreição pedagógica. Tenho clareza disso. Porque além de dá o /pa/, /ta/, /da/, /sa/... eu cantava com meus alunos, levava a letra de musica. Cantava muito. Minha sala era do lado do gabinete da diretora. Ela ia lá: "Cantando de novo?" E eu: "É". Eu cantava e encantava gente, porque eles aprendiam. E levava muito poema, lia muitos contos de fadas porque eu sou apaixonada. Meu pai e minha avó foram grandes contadores de histórias. Então eu acho que eles aprenderam por isso. Não por causa do /ma/, /ta/, /sa/, /la/... não! Pode ter ajudado, mas muito pouco. Mas eu acho que esta questão, foi porque eles já eram letrados. Porque hoje a gente fala em alfabetização e letramento. Então eu acho que eles já eram letrados por conta disso. Foi uma ressurreição total. Eu ia contra tudo e contra todos. Então a minha vida foi essa. Quando cheguei aqui na escola, eu comecei de novo a querer os primeiros anos e encontrei esses parceiros...

LINCOLN: Aí tinha uma disputa já, né?

OLGA: Não...

ALICE: Não, não teve não.

OLGA: Já éramos amigas!

ALICE: Éramos nos três que ficamos e a Cidinha. Cristina teve interesse, mas nós três que ficamos com a CA.

LINCOLN: Antes de passarmos para Stela e para Patrícia, para elas falarem de onde elas vieram, eu vou convidar a Jonê para ela se juntar a vocês, porque é mais um pedacinho da escola. Pedacinho não, pedação!

STELLA: Mas tem algo assim, que eu acho importante eu falar, porque a minha história, ela é 
uma história que vem do município, mas quando eu cheguei aqui, eu me sentia uma ladra. Porque eu sempre tive o interesse, em todo meu trabalho sempre fui voltada para os anos iniciais, né? O meu trabalho no município se constituiu basicamente como professora alfabetizadora. Eu só tive uma experiência com uma turma de quarta série, mas assim sempre pegando turma nos anos iniciais, e eu me lembro que meu viés era um viés político. Por quê? Eu fazia do meu trabalho... nunca fui filiada a nenhum partido, mas eu dizia que tinha um partido que era alfabetizar. Era o meu partido. Eu conversava muito comigo sobre isso. Eu sempre parti do princípio de que toda criança tinha direito a aprendizagem e tinha que sair da escola aprendendo a ler e a escrever. E era muito engraçado, então eu fiz do meu trabalho em sala de aula um trabalho político. Quando eu cheguei aqui, e eu descobri o pulo do gato com as minhas parceiras e com a Cristina, inclusive. Porque a Cristina era uma pessoa assim que facilitava o meu acesso à sala de aula; ela gostava muito que eu ficasse com ela, para ajudar as crianças, enfim, esse trabalho de parceria. É como hoje é tão comum entre nós, quando nós temos a ajuda das bolsistas, das nossas colegas professoras quando estão conosco dentro de sala de aula. Então, a Cristina ficava ávida, e eu adorava ficar com a Cristina.

OLGA: Ela é ávida.

STELLA: Então eu aprendi muito. E eu levava... Eu falava: "Meu Deus!" Era uma felicidade assim. Era uma felicidade muito grande porque está acontecendo o que eu sempre sonhei que pudesse acontecer. Então eu comecei a ser uma professora que levava informações. Eu circulava as informações que eu tinha aqui. Eu também tive o privilégio de participar de um curso com elas, de um curso da Escola da Vila lá no hotel no Flamengo, no Hotel Novo Mundo. Eu assim, chiquérrima, me arrumei para ir naquele hotel. Enfim, eu comecei a frequentar também ambientes que eu já estava distanciada. Ambientes de formação, ambientes de dúvida, ambientes de embates, porque elas brigavam e eu ficava chocada com as discussões! Eu saia daqui assim: "Meu Deus, que é isso?" Mas chegava no dia seguinte, estava todo mundo tomando café da manhã junto, conversando de novo, brigando de novo. Então, essa troca e essa desconstrução daquele mundo idealizado, arrumadinho, do mundo pedagógico... O meu mundo pedagógico era muito levado por essa idealização. Eu fui, ao mesmo tempo, desconstruindo isso aqui e me formando e transformando a minha prática como professora do município com classes populares, né? Porque nós tínhamos um grupo pequeno aqui de classe popular. Mas, no município, 
então, era uma coisa assim mais forte, mais presente, mais real. E eu até dediquei o meu trabaIho do mestrado a esse processo de formação com professoras do município. E sempre disse que iria dedicar o meu do doutorado ao CAp, né? Porque... Mas eu falo dessa ponte, né? E eu até me considero assim uma professora que me tornei com o tempo uma referência no munícipio, nos meus espaços de atuação, com a experiência da prática aqui, né? E, claro, com a minha formação em outros espaços também e na Universidade.

NALU: Stella e Olga, eu acho que pegaram mais essa etapa, aquele momento em que o Departamento passa a ter dois professores por turma. Queria que vocês contassem um pouco isso. Porque isso foi uma mudança de concepção dentro do Departamento. E aí, é claro, em função de projetos. Então, que a gente retomasse, pegasse essa parte e relatasse um pouco esse momento, que é um momento importante na história do DEF, para a gente daí seguir adiante...

OLGA: Eu acho que isso aí começou exatamente com o projeto de extensão lá no Borel, porque já tínhamos outros professores que ficavam nas turmas, enquanto nós íamos dar nosso curso no Borel. Depois começamos a abrir para outros municípios do Rio de Janeiro: Magé, Nova Iguaçu, Duque de Caxias, em primeiro lugar lá na FEBF, o nosso primeiro grande salto.

STELLA: Nem chamava FEBF. Era um CIEP, que depois foi para a universidade.

OLGA: Nem era FEBF. É verdade.

LINCOLN: Isso era registrado como projeto de extensão?

OLGA: Era. Projeto de extensão.

NALU: Daí a necessidade de ter uma pessoa que ficasse na turma, para que acontecesse essa saída, então isso começou a ser mais constante.

LINCOLN: Vocês lembram que época foi essa?

STELLA: Quando eu entrei, entrei para substituí-las quando elas iam dar os cursos no Borel.

PATRÍCIA: Isso foi em 1993?

STELLA: Não sei... Elas dizem que não. Eu digo que sim

OLGA: Aí são as desmemórias....

LINCOLN: Eu sou de 1995. Eu não me lembro de Stella. Eu costumo lembrar bastante das pessoas.

STELLA: Eu tive meu contrato interrompido.

ALICE: Mas sabe o que é... 
NALU: Mas, em 1995, Stela estava, porque, quando eu cheguei, eu peguei um contrato em 95, eu ficava substituindo vocês para irem ao curso, e, em 96, eu já era efetiva.

LINCOLN: Como eu posso não lembrar da Stella? (risos).

NALU: Aí eu dividia com Alice, em 96, como efetiva. Quer dizer, já começou a ter... A Alice, eu acho que era coordenadora e dava aula toda semana. Eu ficava na sala, dividia a turma com ela. Foi o início dessa discussão de uma nova concepção. Porque aí cresceu e se criou uma nova.

ALICE: Porque aí se criou outro processo. Primeiro havia substituição...

STELLA: Eu fui contratada para substituir.

OLGA: Você foi a primeira contratada para substituir oficialmente.

ALICE: Mas quando a Dirce era Chefe de Departamento e eu Subchefe, nós tínhamos carga horária para ser chefe e subchefe e aí nós dividíamos a mesma turma. Isso foi em 94 . Então a gente tinha essa divisão, isso aí já tinha começado nessa época e depois foi se intensificando. Porque aí apareceram várias sugestões do pessoal, da direção do Colégio e do Centro de Educação e Humanidades para a gente diminuir a nossa carga horária em sala de aula, e para a gente fazer. Nós resistimos.

OLGA: Oficializar, né?

JONÊ: Alice, só você e Dirce dividiam turma? As outras não?

ALICE: Sim.

JONÊ: Isso causava mal estar para os pais?

ALICE: Não, não. Ninguém queria ser Chefe de Departamento.

PATRÍCIA: E continua até hoje.

LINCOLN: Eu lembro de uma história que é contada sobre vocês, que é a seguinte: Que havia uma grande resistência em se entender porque duas professoras compartilhando uma turma. Porque isso não é dividir, é compartilhar. E que houve uma discussão na Universidade, naquele momento em que a professora Maria Lucia Weiss era do Centro. Havia um professor que era da enfermagem, que era diretor do Centro de Biomédico. E que a discussão chegou inclusive no âmbito da COPAD, da Comissão Permanente de Avaliação Docente. E os diretores de Centros resolveram trocar os seus relatos. Ao invés do Centro de Educação e Humanidades relatar as Unidades dos seus Centros, esses relatos passaram para as mãos do Professor Marcio Tadeu, da 
Enfermagem. Aí, o Marcio Tadeu se sensibilizou muito com a questão de vocês, e defendeu dar concursos e cargas horárias para vocês. E quando eu cheguei no Centro, essa história foi narrada. Eu já não lembro se era a Dirce, ou era a gestão de Leila e Elaine, pois elas foram participar de uma reunião e eles se sensibilizaram.

NALU: Já foi na gestão de Leila e de Elaine.

ALICE: Havia uma resistência, porque a gente não queria diminuir a carga horária na sala de aula.

NALU: Mas foi antes desse período. Porque isso foi um período anterior. Depois que chegou aqui, quando já estávamos aqui, que esses projetos começaram a se intensificar e aí se fez uma discussão de que não poderia ter uma turma ou outra. E que todo mundo tinha uma obrigação com extensão, com pesquisa, e todos eram professores universitários que estavam muito ligados ao CAp, que iria se tornar um Instituto, e aí se fez o documento, que era o documento "Novas Concepções do DEF", que teve participação de Celi e de Angélica.

LINCOLN: Ainda não era Instituto.

TODAS: Ainda não era.

NALU: Aí se oficializa isso. Tem um momento de preocupação dos pais: "Ah, isso vai dar ou não vai dar certo". Mas, logo no ano seguinte da primeira experiência, essa discussão já não existia mais, porque todo mundo viu que isso foi um ganho.

STELLA: Olha, eu vou lembrar aqui, porque recordar é viver. O José e a Angélica, os dois professores deste Departamento, ainda nessa época, nessa época do curso lá no Borel, eles já faziam composição. Eles não eram [da equipe do curso], os dois, no caso. O José tinha já um projeto de pesquisa, eu não lembro se ele já estava cursando doutorado ou mestrado, e a Angélica já tinha feito. Mas os dois, eles davam aula para a segunda série naquela época. E eles já faziam essa composição.

NALU: Mas ele estava de licença PROCAD.

STELLA: Ele tinha um projeto de pesquisa. Ele já tinha bolsista lá no outro prédio, eu me lembro.

OLGA: Ele e a Angélica foram os precursores.

STELLA: Nesse sentido, nessa posição, eu dividi turma com o José. No meu segundo ano de contrato aqui com o colégio, eu compus com José Gondra, para ele poder ter carga de pesquisa, 
para ele poder ter tempo de carga de pesquisa e ele acompanhava bolsista. $E$ a Angélica também.

NALU: Eu lembro que dividi com a Angélica, assim que cheguei.

OLGA: Depois do Borel, nós fomos para o Instituto de Educação. Ficamos, eu acho, quatro anos lá. Margarida deve lembrar bem disso. Ela era nossa parceira lá. Eu acho que ela era coordenadora de um grupo. Então incentivou muito também. Ficamos quatro anos. Jacqueline também. Quatro anos no Instituto de Educação, e dali, criamos asas e fomos para Magé, Nova Iguaçu, Caxias e depois ficamos 6 anos em Mesquita.

LINCOLN: Quando você diz assim: "Nós fomos, nós ficamos", isso era um grupo? Faço questão de explicitar essa ideia, ou já era já uma lógica do Departamento?

OLGA: O Departamento já tinha assumido esse grupo. Eu digo nós, porque normalmente era o mesmo grupo. Porque nesse projeto de extensão nos éramos um grupo praticamente coeso.

PATRÍCIA: Era uma das ações do Departamento?

OLGA: Era um projeto do Departamento.

STELLA: Era um projeto do Departamento. Quando Alice se aposentou, você, Olga, passou a ser coordenadora. Aí fomos eu, você [Olga] e Glorinha, praticamente.

OLGA: A Cristina entrou pouco, mas quem assumiu mesmo fomos nós. E ficamos até 2010.

LINCOLN: E, para a Alice ficar sabendo um pouco mais da história do Departamento, eu vou para Jonê. Como vai chegando a Jonê e depois a "dona" Patrícia?

JONÊ: A pergunta é como eu cheguei ao CAp?

LINCOLN: De onde você veio? Como é que você veio parar aqui e qual foi o cenário que você pegou?

JONÊ: Eu chego num momento do CAp, eu chego aqui em 2003. Então já é uma virada em que a gente já tem as turmas com dois professores, e que o CAp já é um Instituto. Então, eu já chego em outro momento. O meu concurso já foi um concurso para Mestre, então já exigia uma titulação. Foi o primeiro concurso que exigiu a titulação de Mestre.

STELLA: O meu já foi o último que não precisava da titulação.

JONÊ: Então a pergunta que eu me fazia, quando eu vim para cá, tinha um concurso na mesma época de 2003 para a graduação, tinha para o DLL, tinha para línguas, eu sou formada em Letras, tinha para o ensino fundamental, ensino médio e, tinha o concurso para o CAp/DEF, 
para os anos iniciais. E era um momento em que a Claudia já estava aqui, uma grande amiga minha, uma parceira de longa data do município, que falava muito do trabalho do CAp. E eu sempre dizia, nos espaços em que eu estava em formação, que meu maior desejo era voltar à Classe de Alfabetização. Porque eu também vinha do município, como alfabetizadora, e, por conta do mestrado, por conta de outros espaços, fui para o ensino superior. E eu estava muito tempo no ensino superior. Aí ficava assim para mim: "Vai ter um concurso". E eu dizia no meu discurso em sala de aula que eu queria muito voltar para ser alfabetizadora, mas ganhando como professora universitária. E eu não sabia que o CAp fazia isso. Eu falava: "Acho um absurdo um professor alfabetizador não ser reconhecido, não ser valorizado". Eu quero ser, quero voltar para a alfabetização, massa reconhecida. Aí quando eu soube que tinha o concurso para o CAp, e que eu ganharia a mesma coisa que eu ganharia na graduação, ou no ensino médio, ou na alfabetização, era a chance que eu tinha e me parecia, naquele momento, única. E hoje eu sei que é. Aí eu fiz o concurso. E nessa época, quando eu fiz o concurso aqui em 2003, eu tinha entrado para o doutorado em 2002, então eu estava, há um ano, fazendo doutorado. E eu sei que de alguma maneira, as pessoas estranhavam. Inclusive os colegas do Departamento, né?

OLGA: José e Angélica faziam.

JONÊ: Angélica já era doutora. Eu estou falando da hora de você fazer a escolha. Acho que a diferença que estava colocada naquele momento é que tinha as outras oportunidades de você entrar. Eu já entrava doutoranda. Era essa a questão. E para dar aula para pequeno.

OLGA: É uma escolha grande.

JONÊ: Era uma escolha.

STELLA: Eu me lembro que eu estranhei.

JONÊ: E algumas pessoas estranhavam mesmo. E era um estranhamento mesmo. Você estava no ensino superior, você lidando com o ensino médio, e você voltar para os pequenininhos, esse é o termo. E passado os 11 anos eu tenho, assim, a certeza da escolha que eu fiz. Em nenhum momento tive dúvida, de querer sair. Eu olho e vejo que era aqui mesmo que eu tinha que estar. Então é com muita decisão, com muita clareza que eu vim fazer parte dessa escolha e desta escola. E eu não conhecia o Colégio de Aplicação da maneira que Claudia conhecia e outras. Porque eu não sou filha da UERJ. Eu não estudei aqui, minha graduação não foi na UERJ. Então, assim, eu tinha notícias dos CAps, notícias do Pedro II, mas a minha realidade era professora da 
rede pública e depois professora do ensino superior da rede privada. Então o CAp era muito novo para mim, todo novo. E quando eu vim, ainda como contratada, em 2003, participar da entrevista, foi para compor a equipe com Stela e Olga. Esse ano Glorinha não estava. Ela estava em outra série. Então tinha sobrado essa vaga.

STELLA: A Glorinha, para compor nossa equipe, ela se reprovou. Foi muito engraçado. Ela ficou esperando a Lurdinha sair. A Lurdinha já tinha se aposentado, mas ela ficou conosco, durante um período, contratada. Porque podia se aposentar e ficar contratada. Aí ela ficou. E a Lurdinha também gostava muito dos anos iniciais. Aí ficávamos nós três. Depois, né, houve essa nossa composição, e a Glorinha se reprovou para voltar a ficar conosco.

JONÊ: Então, quando eu cheguei aqui como contratada, fui entrevistada por elas.

LINCOLN: Foi sabatinada por elas?

JONÊ: É. E eu falava com muita empolgação sobre leitura e escrita e não conhecia isto aqui.

LINCOLN: Com as musas da leitura e da escrita! As musas da alfabetização.

STELLA: Hoje em dia a gente encontra o Raul e ri demais. Porque ele falava sempre isso.

OLGA: É meu vizinho, encontro sempre.

JONÊ: E aí, de 2003 até hoje, 11 anos no CAp, eu venho acompanhando a mudança que este Colégio também está passando. A gente vendo a extensão, a luta do Departamento para conseguir carga para a extensão. Hoje nossas lutas por cargas continuam. Mas, assim, hoje o Departamento tem uma característica da sua inserção na extensão, na pesquisa, na orientação, e a gente tem, em sala de aula, todo o tempo, os bolsistas. Então, assim, lidar com a formação do professor, a formação inicial, estar junto com a formação das crianças. Então, assim, o trabalho no CAp da UERJ, especialmente, porque hoje eu conheço outros CAps que já me convidaram a estar em outras bancas de concurso em outros espaços. Os espaços dos CAps são espaços privilegiados, são espaços legais. Mas o CAp-UERJ tem outro fascínio. A gente fala sempre com muita alegria deste espaço. A gente veste a camisa muito fácil. $\mathrm{E}$ quando as crianças do primeiro ano fazem a incorporação, a gente vê que essa incorporação é contagiante. Incorporamos nós, incorporam as crianças, os pais. Vestir a camisa do CAp é muito fácil... já vai chorar, né, Lincoln?

OLGA: Jonê, você falou das bolsistas em sala, né? Como não só elas aprendem, como nós aprendemos também. Porque elas também ficam nos sugando, no bom sentido, e a gente se 
obriga também a se organizar, estudar, ver o que vai falar, a dividir o material. É uma coisa assim fantástica. Que pena que as outras escolas não possam viver isso.

JONÊ: Então, assim, só para fechar, eu sentei ali e ouvi a Olga falando, fazendo 50 anos de magistério... é gostoso, é simbólico. "É" 50 anos! Olga, com orgulho, com vigor, com afinco. Você fala de uma maneira... é emocionante te ouvir falar. É prazeroso poder dizer isso para você, você contagia, nós já dividimos mesas e eu sempre quis te dizer isso. Então, assim, nós temos poucas oportunidades, nós aqui sabemos disso, de nos ouvir, de falar, né? Porque no cotidiano a gente vai correndo, vai correndo, a gente sabe que tem ali os pares, mas a gente muitas vezes, não consegue se ouvir. E a gente, que fala tanto do ouvir e do falar, do compartilhar, a vida nos impede muito disso. E toda a oportunidade que eu tenho para te ouvir é, com humildade, tirar o chapéu e ficar feliz, de estar aqui nesses 50 anos com você. É muito gostoso mesmo, e com as outras parceiras também. Estou só sendo simbólica, pelos 50 anos. Não tive oportunidade de conhecer a Alice. Conheço a Alice, mas não cheguei a trabalhar. $E$ as outras parceiras, eu acho que a gente tem sempre que glorificar no sentido de pensar, né? É que a gente, fazendo cotidianamente história. Como disse a minha filha, que hoje está no sexto ano: "Meu professor disse que História a gente faz todo dia". E é isso! História a gente faz todo dia. A gente está fazendo história. E que bom que o CAp se refaz, e que outras venham, né?

OLGA: Que bom que todas tivemos filhos aqui...

JONÊ: Que é um outro orgulho.

OLGA: É um outro tipo de orgulho, porque a gente vive o outro lado. E é muito bom. A gente também tem histórias assim, fantásticas, para contar. Não delas, mas delas enquanto alunas e dos professores que elas tiveram.

JONÊ: Como escola, só para lembrar do que o Lincoln falou do Departamento, como a escola tem contradição, tem disputa, tem conflitos, tem tensões, entendeu? E a gente não abre mão desse espaço. A gente reconhece esse espaço como constituinte da escola. Esse espaço idealizado, só quando a gente fala dele, que a gente fala como idealizado. Mas a gente vive uma escola de conflitos.

LINCOLN: E a sua história, professora Patrícia? Pegando o gancho.

OLGA: Patrícia aí quietinha...

PATRÍCIA: Eu estou quieta porque primeiro, eu me sinto privilegiada, né? Por estar aqui no 
meio de tantas pessoas que têm histórico muito maior que o meu aqui dentro. Mas ouvindo vocês, eu diria que, digamos, sou aquela que, se eu pudesse usar uma metáfora, "estranha no ninho". Porque eu não vim de outro município, eu não sou do Rio de Janeiro.

LINCOLN: Com esse sotaquezinho...

PATRÍCIA: Eu venho, sim, de um histórico desde o início da minha atuação com docência dos anos iniciais. Eu sou do tempo em que ainda se formava no ensino médio, o magistério, em que se podia optar pelo científico e pelo magistério. Optei pelo magistério. Depois fiz uma graduação, que ainda havia naquele momento, uma graduação que habilitava para as séries iniciais: "habilitação em Deficiência Mental". Mas sempre meu percurso foi entre a escola especial e a escola regular. Um turno em uma e um turno na outra. Com os anos iniciais, sempre no processo de alfabetização. Na primeira escola em que eu trabalhei, comecei com educação infantil, a escola foi crescendo do jardim, para o pré, do pré para o primeiro e, eu fui passando...

LINCOLN: Foi sendo aprovada, né?

PATRÍCIA: Isso, a escola foi crescendo e eu fui crescendo com a escola. E, em um dado momento da minha vida, em 2002, eu venho morar no Rio de Janeiro, que é quando eu começo a me inserir nesse outro ambiente de formação, ainda, também. Que é quando eu venho fazer o mestrado, quando volto a atuar em escola especial, depois numa escola da rede particular ali na Tijuca. E, nesse meio tempo, surge o concurso, em 2007, para o CAp. E eu faço esse concurso. Então o meu foi o último que teve para mestrado, para mestre ainda. Depois passou a se exigir doutoramento. E eu faço esse concurso, e eu entro num ano em que o Departamento vivia um debate sobre a inclusão, que agora estava ouvindo vocês falando, sobre essas iniciativas de se criar novos procedimentos e novas possibilidades para todos. Eu entro em um momento em que todas vocês se questionam que é preciso atenção para o fato de que todos podem aprender. Independente de onde vêm, do nicho social do qual vêm. Do acesso à informação que têm. Além desses, a escola começa a pensar também naqueles que tinham um desenvolvimento diferente. Não é questão de falta de acesso à formação ou de acesso à cultura dada, construída socialmente. A escola começa a se perguntar como ensinar a criança que não tem aquele desenvolvimento habitual, ao qual, por séries, a escola se habituou a ensinar. Aí entro eu e uma outra colega na época, no mesmo concurso de 2007, ambas com uma especialização de formação, desde a graduação, na área da educação especial. E aí, de lá para cá, esse meu percurso 
tem sido inicialmente nos anos iniciais, atuando com o terceiro ano, depois eu tive a grata surpresa... A gente fala que o Instituto de Aplicação é um Instituto de formação para os nossos graduandos, de pesquisa, de extensão. E eu tenho assim, muito nítido, que, para além disso, e antes disso, é um ambiente formação continuada. Porque a minha formação, desde o momento em que eu entrei aqui, ela foi resignificada e ela tem se dado de lá para cá, todo dia. Todo dia eu saio daqui, eu chego aqui com uma ideia, com uma hipótese e saio com uma outra. Todo dia. Todo. E aí, nesse meio termo, são 7 anos que eu estou aqui na Instituição. É estimulante, mas é desgastante. Então, nesse processo, que tive o prazer de dividir os anos iniciais com Olga, sempre aquela coisa de escutar o processo, de tentar entender que dinâmica é essa que se constitui que a gente sempre lê. Vocês falavam de 1980, 1990. O meu processo de formação inicial como professora era nesse processo que vocês estavam se constituindo enquanto Colégio de Aplicação. E as coisas que vocês falavam com um, falavam com outro. Eram os teóricos que eu lia lá no meu Estado, quando estava em formação. Isso é bom de ouvir porque dá, digamos, a imagem e ação ao que se falava até então. Esse percurso, então, entre a sala de aula, lidando como professora dos anos iniciais, foi se configurando uma outra ação além dessa, que veio a compor essa. E eu acho que essa é que é a ideia mais bacana, quando vocês falam de novas reflexões, de diversos caminhos que poderiam ser dados para a mesma resposta, para aquele aluno. Eu acho isso tão sério, isso assim mexe muito, me é muito caro. Pensar em diversos caminhos para todos. (chorando)

JONÊ: Porque a escola tem a mania de dar um caminho só.

PATRÍCIA: A escola, a sociedade, ela muitas vezes tolhe antes de enxergar o sujeito que existe nele. Então eu vejo isso, não só pelo lado da educação especial. Eu vejo pelo lado do ensino público. Vocês, que trabalharam em comunidades como no Alemão, Borel, Comunidade do Pinto, que eu nem sabia que existia,... da Maré... Então, olhar para esse sujeito e ver possibilidades, então esse é meu ideal. Esse é meu espaço. E aí poder trabalhar hoje numa escola na qual houvesse essas possibilidades, que também é um dos embates bastante presentes, ao mesmo tempo que eu vejo vocês falando do histórico da constituição da dupla, da regência por dois professores, que eu acho um pulo do gato, temos um processo no qual podemos olhar as possibilidades.

JONÊ: É interessante como isso se naturalizou. Vendo elas falarem do começo, hoje nenhum 
pai questiona isso, já é naturalizado. Quem são as duas professoras, quais são os dias delas?

NALU: Já faz parte da cultura.

PATRÍCIA: Nós estamos num outro processo de naturalizar uma outra prática. Uma prática que venha agregar a essa. Não é uma prática paralela. Ela vem compor um olhar..., não que não houvesse antes, mas que venha a dar um detalhamento para alguns processos de ensino e aprendizagem de alguns alunos. Também houve bastante discussão, bastante colaboração, dúvidas sobre como fazer isso em relação ao que hoje nós temos no Ensino Colaborativo.

JONÊ: Que nós nomeamos de Ensino Colaborativo.

PATRÍCIA: É, que nós nomeamos.

LINCOLN: O que os "Ações dos Docentes de Inclusão" talvez tenham ajudado ou contribuído para isso que Patrícia está falando hoje? Será que tem uma relação, essas coisas?

PATRÍCIA: Uma relação não. Ela não tem uma relação, ela é o ponto inicial. É o ponto de partida. Porque assim como Alice falou no início, a prática se antecipa à teoria. De certa forma, foi assim que aconteceu também. Embora houvesse uma teoria, em termos de uma formação inicial para esse graduando, por isso o projeto de Iniciação à Docência, dele estar aqui, visualizar, compartilhar, ver o espaço cotidiano da escola, foi criado então, em 2006, um projeto de Iniciação à Docência por conta de uma demanda posta. Que na época eu ainda não estava aqui. Professora Nalu, professora Celi foram as professoras que criaram o projeto de Iniciação à Docência voltado às Necessidades Especiais em Processos de Inclusão, por conta de uma demanda de uma aluna específica, com um desenvolvimento muito peculiar. Não era uma dificuldade de aprendizagem meramente, era outro desenvolvimento que se agrega a outras questões, além das dificuldades do aprender no primeiro ano isso, de aprender no segundo ano aquilo. Não era só um tempo diferenciado. Era um procedimento diferenciado. Eram técnicas, era uma didática de se pensar diferente.

LEILA: Olha ações de inclusão... é muito mais... foi muito mais trabalhado agora. A gente sempre teve aluno difícil, teve. Mas não tinha uma ação que trabalhasse esse aluno. Até porque a nossa formação não permitia. Nós tínhamos uma coisa muito mais... nossa, de cada um, de incluir ou não. A gente tem um exemplo importante, era uma criança dificílima, que precisava de um atendimento. Lincoln lembra disso, daquela vez que ele estava batendo e foram me buscar, porque eu conseguia ter um diálogo. Mesmo quando ele estava nervoso. Tanto que ninguém 
entendeu. Foi uma criança que me deu problema o ano inteiro. Aí ele repetiu o quarto ano. "Qual a turma que você quer?" "A "dele". Faço questão que "ele" fique." "Você é maluca!" Mas eu sabia que eu tinha um diálogo com "ele". Que eu conseguia, mas não tinha apoio de ninguém. Não existia uma preocupação da inclusão dessa criança. Acho que a preocupação começou a existir quando uma outra criança entrou. Que aí a gente se deu conta, de como trabalhar com ele. E foi muito mais a família que nos orientou a trabalhar com essa criança do que nós. E aí nós começamos a perceber que algo tinha que ser feito. Aí acabou chegando ao processo de inclusão. Eu não sei. Na minha visão, eu acho que foi essa segunda criança que despertou. Porque era uma situação complicadíssima.

LEILA: A gente não tinha como trabalhar; trabalhava no empírico. Vou fazer isso... E já tinha muitos. Tinha aquele outro menino, como era o nome dele? Ele ainda deve estar lá. Complicadíssimo. Agora não. Agora já tem um grupo que efetivamente trabalha com isso.

LINCOLN: E importante é o empenho do Departamento nisso. Porque objetivamente é ele que congrega isto.

LEILA: É ele que dá isso. Até porque tem a ver com esse olhar diferente que a gente tem. Eu até entendo o professor do sexto ano em diante. Ele entra 50 minutos, a gente está com a criança o dia inteiro. Então você percebe muito mais do que em 50 minutos, $45 \ldots$

LINCOLN: Às vezes até na recuperação paralela. Que vocês também praticam. Nalu falou muito dessa articulação das ações docentes que começam com uma atividade, depois vira projeto, depois vira disciplina por meio da recuperação paralela.

LEILA: O Departamento tem essa prática. A gente começa fazendo individualmente e depois o Departamento tem a clareza de começar a discutir e transformar num projeto.

STELLA: Eu me lembro de outros alunos que nós tivemos aqui, ainda naquela época na Haddock Lobo. E que não tiveram essa oportunidade, e eu me lembro o quanto nós nos inquietávamos com aqueles alunos. Com aquelas histórias, né? Alice ficava indignada. Várias vezes estava na hora do recreio, perguntando conversando, porque a gente sempre tinha recreio e entrada pedagógica. A gente chegava antes para conversar, todo mundo chegava com uma notícia de jornal, ou algum assunto sobre o nosso cotidiano. E nós já tivemos alunos que foram embora e que nós não tivemos como ajudar... A Alessandra, a Rose...

NALU: Gente, é impressionante lembrarmos dos mesmos, eu estava pensando nessas duas. 
ALICE: A Alessandra, o quanto nos causava.

STELLA: Inquietação. Como fazer com essas duas?

NALU: Eu ficava... eu fico lembrando da Cidinha.

JONÊ: Interessante como essas pessoas, eu conheci depois, mas elas desistiram da escola. A família, de alguma maneira.

ALICE: Mas, assim, a Alessandra, de uma maneira.., foi muito bom o que eu ouvi da mãe dela, para mim foi muito gratificante. Porque ela falou assim... ela entrou na escola, assim na época com cinco anos me lembro que ela era aluna da Cidinha. Cidinha desesperada, mas ela assim ela mal falava...

NALU: A Rose e a Alessandra eram da mesma sala...

ALICE: Ela babava. Então, assim, era uma criança que surpreendeu. E depois ela foi minha aluna, mas o que eu ouvi da mãe dela depois... Quando a mãe dela achou que era melhor ela não continuar mais e eu também ia me aposentar, mas ela achava que era melhor sair do colégio... Ela falou assim: "Olha, eu tenho certeza que se ela não tivesse vindo para essa escola, ela não teria tido o desenvolvimento que ela teve". Isso foi muito gratificante. Ouvir de uma mãe falar isso, e eu fiquei dois anos com ela, Cidinha ficou dois anos... e eu fiquei dois anos. E foi muito bom ter ouvido isso. Depois, eu, por acaso, a gente morava mais ou menos perto, e eu me encontrei com ela depois disso... ela está uma moça...

PATRÍcIA: É interessante como é que, o espaço em sala de aula, quanto mais diverso é, mais contribui para esse processo de ensino. E para aquilo que Olga estava dizendo, como se aprende. Se aprende na diversidade, se aprende nesse...

JONÊ: E acho que enquanto Colégio de Aplicação, por muito tempo, o CAp e os Colégios de Aplicação, e mesmo os colégios da rede, a gente não recebeu esse alunado. Esse alunado sempre estava na escola especial.

OLGA: Até estava nas nossas escolas, mas eles eram esquecidos.

JONÊ: E eu acho que esse momento que o CAp...

NALU: Os casos mais evidentes como surdez, que é o tipo que... é o caso que a gente... não é um caso diagnosticado. Isso, a gente observava coisas, mas você não tinha onde pegar. E esse caso específico que a gente inicia isso é o caso de surdez... muito incisivo. Nós tínhamos tentado fazer o projeto, mas não tinha sido aprovado, aí ele volta e eu pego, e aí a gente refaz esse 
projeto e de repente a gente consegue. 0 primeiro projeto de iniciação docente a umas bolsistas para auxiliar E aí, quando eu escrevo lá esse projetos Necessidades Especiais...eu acho que era isso, né? Em Processos de Inclusão. E essa criança na minha sala, e eu não tinha formação. Então eu fiquei angustiada. Pelo menos eu consegui isso. E aí eu tinha bolsistas, e a gente foi ali tentando, fazer alguma coisa. E assim, a minha alegria, quando chegaram a Patrícia e a Márcia, porque elas tinham uma formação. Eu estava fazendo muito as coisas na intuição. Correndo atrás de uma formação que,até então, eu não tinha e a gente fazendo o que podia. Mesmo assim, nós tivemos uma ajuda incrível com essa criança. E aí, chegando gente com formação, imagina o quanto mais poderia estar avançado. Aí eu saio de licença, para o doutorado e é tão impactante, porque, como eu fiquei afastada durante o doutorado, quando eu volto, aquele projetinho minúsculo de iniciação à docência com uma bolsista tinha se transformado num grande projeto do Departamento e da escola e com uma extensão, uma possibilidade de inserção grandiosa. Então, talvez para mim, que escreveu uma coisinha mínima e aí você retorna e vê a coisa grande, é muito impactante. Talvez vocês estando aqui, talvez nem tenham essa sensação que eu tive. Porque eu saio e volto e encontro um negócio gigantesco. Isso foi muito emocionante.

JONÊ: A gente vai vendo esse impacto Nalu, e é bom a gente recuperar um pouco isso. Como você está dizendo, era uma bolsista, depois a gente foi vendo projetos com aumentos de bolsas e hoje a gente briga por 25 horas de docente para olhar, continuar olhando essas necessidades especiais de inclusão. Então eu acho que a gente fazer esse recorte é interessante até para nós mesmos nos olharmos.

PATRÍCIA: Partiu de um projeto de Iniciação à Docência em que os bolsistas atuavam na sala de aula com essa perspectiva, da colaboração com a gente.

NALU: Porque às vezes a gente não tem essa noção.

LINCOLN: São 100 horas.

PATRÍCIA: E isso porque a gente pensa um turno para um aluno. Hoje nós temos 100 horas. Quando o Lincoln pergunta sobre a relevância do projeto de iniciação a docência, eu acho que ele foi um norte de toda a ação que nós temos hoje, de uma certa forma, estabelecida.

LINCOLN: Eu vou emendar uma outra pergunta. No que isto efetivamente influenciou em alguma mudança da concepção pedagógica? Estou copiando o roteiro que Nalu e Andrea fizeram.

PATRÍCIA: Eu gostaria que assim... eu posso até contribuir com a fala, mas eu gostaria de 
compartilhar, porque eu me sinto comprometida de dizer o que pode contribuir pedagogicamente. Olga divide essa realidade do que é que é a ideia que em alguns locais chamam de "Bidocência", outros de "Ensino" e que nós optamos por "Ensino Colaborativo", para essa ideia do atendimento educacional especializado, posto na política nacional, que aborda a sala de recursos multifuncional com computador. E nós, enquanto essas falas, esses diálogos, essas análises sobre como fazerem e como se ensina para então aprender, fomos vendo que, somente no contraturno, não favorece a aprendizagem.

OLGA: Tem que estar no meio dos dois.

JONÊ: Eu queria, Olga, até falar antes de você, que está vivendo a situação que ela está falando especialmente, que é da Bidocência desse acompanhamento. Eu falo do lugar de professora que não tem, necessariamente, esse acompanhamento e essa Bidocência, falo como professora do Departamento. A gente vai aprendendo a olhar para os alunos todos de modo diferente. A gente vai partilhando, vai ouvindo aqui, vai se incomodando, vem cá me ajudar a ver... não, ele não tem nada de diferente. Ele tem uma necessidade tal, tal, tal. Passa a fazer assim, assim com ele... Aí você começa a facilitar para aquele aluno, conversas com Patrícia e com os pares fazem a gente perceber isso. No que você começa a olhar para um que você pensa ter necessidades especiais, você ajuda o todo. Ajuda a turma e ajuda a sua formação. Porque assim, pedagogicamente, é outra maneira de olhar. Você parte do princípio de que todo mundo tem necessidades especiais. E na verdade temos. Então tem sido um aprendizado, assim, muito grande.

OLGA: Não só nós, Jonê, porque os próprios alunos começam a se ver de forma diferente e a ver aquele aluno como outro, como parte da turma.

PATRÍCIA: Como parte e não à parte.

LINCOLN: Isso, nos seus entendimentos, tem a ver com a escola experimental? Com a ideia de escola experimental?

LEILA: Exatamente. Que é a semente do CAp. Ela nasceu como escola experimental. Então tinha que ter por obrigação esse olhar do experimento.

LINCOLN: Quando vocês trazem essas memórias todas, na verdade falam de práticas que até hoje influenciam. As pessoas de alguma forma tentam reviver algumas dessas práticas. A gente percebe que hoje a escola recebe, de novo, um publico diferenciado. Estamos vivendo um outro 
momento da história da Instituição, no qual se adota uma política de cotas. Como é que vocês enxergam isso na natureza do seu Departamento? Departamento que tinha um vestibulinho, passa a ter um sorteio, que era um sorteio que tinha características bastante peculiares. E que agora vive, neste momento, esse novo desafio. O que você pensa disso?

LEILA: É um desafio grande. É repensar de novo. Eu acho que é o momento de o Departamento se reinaugurar. Eu acho que esse grupo que entra, tem outras características. Algumas dos grupos que nós trabalhávamos, mas tem outras características. E o Departamento tem que, nesse processo todo de se reinaugurar, tem que voltar a sentar e discutir. A ideia é essa, qual o nosso trabalho que eu acho que é muito isso que o Departamento faz. O que a gente pode fazer para ter esse grupo conosco e não discriminá-lo de alguma forma. É integrálos e tocar para frente isso aí. Eu acho que é um momento riquíssimo do Departamento estar se repensando.

JONÊ: Eu estava olhando as portas do primeiro ano e olhando os desenhos das crianças e pensando assim: "Como a gente sofreu aqui". Eu sofri com uma aluna especificamente, e outros tantos sofreram, que não sabiam se desenhar com a cor marrom. Para desenhar tinha que ser a cor de pele, o tal salmão. Então, eu tive uma aluna negra, que se desenhava toda loira, ela não se via... E eu observei nos desenhos de primeiro ano e sei que temos alunos de cor marrom, que eles se desenham assim. Então isso é só um exemplo. Mas eu acho legal, Stella, a gente vê como é esse processo.

OLGA: Mas porque a gente volta e faz pensar: "A sua cor é essa?"

JONÊ: Mas o legal é como a escola toda se modifica. A gente tem um projeto que é: "Como lidar com a diferença na escola". E essa diferença, ela para isso e tudo, ela olha todas as diferenças; somos todos diferentes.

OLGA: Quem é o diferente?

JONÊ: Assim eu tenho aprendido muito aqui.

ALICE: Porque eu acho assim, escola, eu vim do tempo em que se enquadrava muito todo mundo.

LINCOLN: Você veio de um tempo em que, para entrar, tinha que fazer uma prova

ALICE: Tinha que fazer prova. Então eu me lembro que a Leila começou a fazer algum estudo sobre a questão das crianças que eram "expulsas" da escola. 
LEILA: Lembro da questão das licenciaturas. É uma discussão que começou lá, e se concretizou recentemente. As licenciaturas são legais. O Colégio nasceu para ser campo de estágio da Faculdade de Educação, com inserção grande na licenciatura. E aí o que acontecia? O professor, na época da criação e até a década de 90, quando começou aquele grupo de trabalho da licenciatura, de se repensar a licenciatura, o professor de prática de ensino era sempre um professor de turma do CAp, e isso se perdeu. Aí abriram... Aí a gente começou uma luta para tentar preservar isso, do professor ser exatamente aquela coisa do experimento. E era um professor de turma, eram aulas... para ensinar os licenciandos e isso se perdeu. As Unidades puderam abrir concursos de práticas de ensino e só algumas Unidades daqui permaneceram com... e o Colégio tinha que repensar alguma coisa, para ter na mão essa licenciatura. Aí foi-se o tempo quando houve muitos projetos de formação de professor, de mostrar principalmente o DEF atuar na formação continuada do professor. Com parcerias fora... e foi muito interessante quando o primeiro segmento foi criado. Não se abriu um único Departamento do Colégio que não tinha inserção, um diálogo, com a Faculdade de Educação, que era o DEF. Nunca teve. E aí, quando as professoras das séries iniciais iam lá e diziam: "Por que a gente não participa? Não faz estágio aqui?" Isso era uma incoerência, mas depois que se abriu, a gente perdeu muito espaço. Então tinha que permanecer esse espaço, daí começa a se discutir o Instituto, para ter uma inserção maior na graduação. Eu acho que é por aí. Aí eu já estava meio afastada, perdi um pouco o fio da meada. Mas é por aí, tá? Agora, o Colégio não pode esquecer que sua razão de ser é o ensino básico. A gente está na graduação, mas o ensino básico tem que continuar a mostrar o que vem mostrando até hoje. Que é um Colégio que precisa voltar a ter a ousadia do experimento. Eu acho que hoje quem experimenta muito mais é o DEF e alguns professores. Você tinha falado da jubilação... A questão da jubilação, o DEF, como um todo, sempre se colocou contra. Todos os momentos em que se discutiu a avaliação, o DEF sempre levou a proposta da não jubilação. Mas nunca foi uma proposta que vingou. E, se a gente pensar, não é só o CAp que jubila como os colegas colocam. Infelizmente o Pedro II tem jubilação e infelizmente escola particular também tem. Eu acho que o mais flexível é o CAp, ainda. Toda a jubilação que o nosso Departamento é contra..., mas o CAp você pode fazer de dois em dois anos. A gente ainda tem isso. Tem aluno que fez de dois em dois anos e têm vários... O processo é um pouco melhor que os outros. Não é tão perverso. Perverso é, mas não é tão perverso. 
NALU: Que até hoje acontece.

ALICE: Pois é. Mas assim, o quanto, de qualquer maneira, isso foi repensado, as coisas foram evoluindo de qualquer forma. Claro que eu acho que uma contratação como a dela, como a da Patrícia que falou sobre isso, é um ganho enorme, frente àquelas questões todas, né? E eu me lembro que a Leila, eu não sei que fim levou, até era bom que ela falasse sobre isso, porque era um estudo bem interessante.

JONÊ: Bem interessante mesmo, como a escola vai se modificando.

PATRÍCIA: A gente pode dizer, só para completar, que, ainda que com os embates, ainda que com os entraves, são sete anos que estou nessa instituição. Então esses 7 anos com projeto de iniciação a docência, que já pegamos com uma continuidade e continuando eu e Márcia Marin, em 2011 se estabelece a primeira equipe para esse trabalho de Bidocência do ensino colaborativo. Então não eram somente as bolsistas, porque até então éramos eu e Márcia, em sala de aula, com a regência de uma turma e nós orientávamos as bolsistas que iam fazer esse trabalho colaborativo. E, a partir de 2011, se organiza uma equipe em que Márcia Marin é a primeira efetiva deste Departamento a compor essa equipe com professoras contratadas.

JONÊ: Muito recente.

PATRÍCIA: Muito recente. E, a partir de 2012, eu venho compor essa equipe, também como efetiva, e aí nós éramos: eu, efetiva, mais três contratadas. Hoje nós somos: eu, efetiva, e mais seis contratadas. Estão as 100 horas aí postas. Para além daquilo que, inclusive, a legislação propõe o que é a deficiência, ou o autismo ou as altas habilidades. Para esse aluno, que até então... Por que ele saía da escola? Por que a família e o aluno, a gente ouve isso principalmente a partir do segundo segmento, "eu quero sair dessa escola". O que acontece com esse processo que não torna mais prazeroso? Não há mais aprendizagem.

OLGA: Ele mesmo se evade, né?

PATRÍCIA: Então, nesses processos de evasão e de exclusão, que é uma exclusão sim, a gente ainda tem bastante coisa para fazer, mas eu acho que esse tipo de processo, nesses 7 anos, dentro desse olhar basicamente, eu acho que é uma engrenagem. Vocês narrando a história, fui vendo com o desdobramento do tempo que foi indo, até o momento em que vocês me dão a palavra. E que, nesse desdobramento, o quanto esses embates, essas reflexões foram quando se constituiu para serem dois regentes, quando se constituiu para não ter mais o vestibulinho, 
quando se constituiu como Instituto e não como Colégio, quando se constitui a ideia de que é necessário outro olhar para compartilhar o espaço que já existe para compor ensino e aprendizagem. Então, nós estamos falando de uma escola de educação básica, mas que vem sendo e vem fazendo seus desdobramentos diante desse perfil de educação básica. Ainda que nela compita dizer: de extensão, pesquisa, graduação, pós-graduação. Por isso, é o que eu digo: a formação é todo dia. A minha é todo dia.

OLGA: Eu estava esperando você acabar de falar. Não sei se eu vou conseguir não, porque eu me emociono, realmente, porque foram dois anos muito valiosos para mim; porque eu aprendi muito com a Patrícia. Aprendi com meus alunos com necessidades especiais. Quando eu recebi a turma, estava voltando de um ano de licença, o ano em que eu ia me aposentar, que ia, mas não fui, e eu voltei em uma turma com dois alunos com necessidades especiais, e eu falei "Meu Deus, e agora? O que é que eu faço? E como faço?" E aí tive a grata satisfação de ter o projeto, de ter a Patrícia comigo diariamente.

PATRÍCIA: Essa turma tem acompanhamento diário, de $2^{\mathrm{a}}$ a $6^{\mathrm{a}}$, com esses dois alunos.

OLGA: Aprendi muito assim, trocando muito. Como fazer para aquele aluno a mesma tarefa da turma. Não era diferenciado, mas de outra maneira. A tarefa era a mesma. E ela ali ao lado da criança, ela ia ajudando a pensar e a ler.

PATRÍCIA: A gente ia redesenhando o processo, não é, Olga?

OLGA: Essa é a palavra mesmo, redesenhando o processo. E como nós trocávamos, como essas crianças avançaram. Como a turma, aceitou essas crianças. Entendeu, né? Não havia, assim, diferença. Um ou outro às vezes dava um "piti", entendeu? Mas muito raramente. E a gente tirou isso.

PATRÍCIA: Mas isso faz parte do processo, da infância.

OLGA: Faz parte também do processo da infância. Mas também nós entrávamos. Patrícia entrava, eu entrava. A discussão era geral, nós e eles. Então eu aprendi muito. E fiquei feliz em ter esses alunos. E poder, no final da minha vida de ensino, aprender mais isso. Como lidar com essas crianças que têm os mesmo direitos das outras crianças. Foram dois anos muito, muito bons. Mais um desafio. Que a gente está vencendo e que eu acho que eu também consegui vencer um pouco, né? Porque também aprendi muito. Aquele susto do início foi se transformando em orgulho. Eu tenho orgulho de ter sido professora desses dois alunos, dividindo com a 
Patrícia e com as bolsistas, que vinham também, que participavam. E tinha a Vanessa que não era bolsista, era professora contratada. Então eu acho que fui privilegiada.

LINCOLN: Em cada momento vocês falaram de novas concepções, de um novo elemento. Ele às vezes incomoda. O novo, ele nos tira da nossa zona de conforto, o novo também nos coloca em processo de expansão. O que é o novo agora? Que novas concepções estão "entrando" aí para vocês?

JONÊ: Eu acho que o DEF abriu uma forma de novo todo dia. Não o DEF só, mas o CAp especialmente, quando a gente não tem ainda - e isso pode ser um ponto positivo - , quando a gente tem, no DEF, pelo menos, $50 \%$ de professores contratados. E aí, a gente tem todo dia uma cara nova, uma situação nova, um professor novo. A minha turma, olha eu sendo possessiva aqui, porque eu estou com ela pelos segundo ano, ela já passou por quatro professoras outras.

LINCOLN: E você é da turma deles.

JONÊ: Então, a cada dia eu tenho, olha quantos possessivos, uma nova parceira, e essa nova parceira vai compondo uma nova turma. Então, quando você me pergunta o que é o novo, eu te responderia que um desses aspectos desse novo que a gente tem é essa renovação contínua, de que o novo é sempre bom, mas eu gosto muito do termo que o Geraldi utiliza, que é... num livro antigo dele, Portos de Passagem, em que ele diz assim: que nós precisamos dessas passagens e nós precisamos de portos de ancoragem. A gente precisa, em alguns momentos, ancorar e parar. A esse aspecto novo, peguemos um fluido o tempo todo. A gente nem sempre, quando a gente pensa que vai ancorar, aí a gente vai para o novo de novo.

PATRÍCIA: Até porque a gente está na eminência de um processo de rede. Não sei se é renovação porque Olga se aposenta, Celi, Cristina e Stella também. Então, assim, quando eu entrei aqui em 2007, há 7 anos atrás, essa composição de inclusive pensar qual é a proposta pedagógica do Departamento, eu tenho isso como parte de referencial que sai. Eu me sinto com um compromisso muito grande com aqueles que vão chegar. Me sinto com um compromisso muito grande com aqueles que virão. E eu já parei para pensar algumas vezes, quando vocês chegaram, quem estava saindo, quando eu cheguei, Angélica estava saindo. Cheguei a compartilhar coisas com a Angélica. Angélica estava voltando do pós-Doutorado dela. Cheguei a compartilhar turma com ela. Então, o novo também é todo dia. Não só pela partitura da escola, pela questão de como se gesta essa escola; a gestão dessa escola não é uma gestão comum, não é uma ges- 
tão que se assemelha a de nenhuma outra escola. E eu não estou há tanto tempo quanto Olga, quanto Alice, quanto Stella, quanto Jonê, no ensino. Mas desde os 16 até os 45, tem um tempinho aí. Embora não seja no ensino público, mas no privado, eu não conheço outra escola que se assemelha à gestão desta escola. Eu não conheço outro Departamento, em outro lugar de ensino básico ou de ensino das séries iniciais, que se assemelha a este espaço e a este lócus de ação docente. Então é complexo; é desafiador o tempo todo e a cada um que deixa o espaço, por conta do seu tempo já gestado, já concluído, aqueles que ficam acho que se imbuem dessa responsabilidade. Se imbuem dessa responsabilidade, porque a gente aprende, como a Jonê disse, a vestir, e depois que se veste essa camisa, tirar é muito complicado.

JONÊ: Entranha na alma.

STELLA: E também o novo, as cotas.

PATRÍCIA: Que vêm com essa discussão muito nova, ainda que neste Departamento, acho muito importante isso ficar posto, neste Departamento já exista um diálogo e um caminho, uma trilha aí percorrida em relação ao que é o acesso com crianças com necessidades educacionais especiais, e não só o acesso, mas a participação delas nos anos iniciais, a permanência com aprendizagem, que só a permanência já vem narrando outros já participaram, mas o que aprender, como aprender, isso ainda é muito novo. É muito novo ainda.

OLGA: Muito desafiador também.

STELLA: Eu não tenho muita coisa a dizer sobre a cota não. Porque o fato de ter as cotas me agrada muito. Acho que foi, assim, um grande avanço. Nós termos vagas para algumas crianças que, talvez, não tivessem a oportunidade.

OLGA: As nossas turmas são muito coloridas.

JONÊ: Eu tenho uma professora que disse assim: "Eu era contra as cotas", uma professora daqui, muito nova, e ela era contra as cotas. Dizia: "Eu não gosto de cotas, mas quando eu vejo a cor dessas turmas eu mudei de opinião, eu sou a favor das cotas". E quando eu escuto a minha filha do sexto ano me dizendo que uma colega chegou para ela e disse numa conversa de onde veio, a menina falou: "Eu sou pobre". E falou o "eu sou pobre" numa voz muito baixa e tímida. Esse relato me impacta. Por que uma criança precisa afirmar que é pobre? Porque ela sabe onde ela está chegando. Ela está pedindo licença para chegar. Então me impacta. Nós temos ainda que muito... 
STELLA: Nós temos mais um desafio quando entra...

NALU: Eles entram e aí o que vai ser?

STELLA: O nosso cuidado com essa nova porta que a gente abriu. O acolhimento. Nós temos a responsabilidade de acolher a todos que entrarem desse modo. E cuidar disso, né? Pedagogicamente, garantindo o que é de direito, então eu me sinto... Uma das coisas que me fez repensar a minha aposentadoria foi isso, me deu uma...

LEILA: O CAp, ele faz, ainda consegue fazer essa leitura de mundo muito bem. O nosso aluno se diferencia sim. Porque eu acho que todos nós temos essa preocupação. De estar lendo muito... Uma vez eu estava conversando, não lembro com qual colega num desses InterCAps, que ele falou: "Interessante, o aluno do CAp tem aquela coisa, ah ele fica reprovado talvez porque nós não dialogamos o suficiente." A gente fica restrito quando manda o aluno do DEF para o sexto ano e aí o que acontece? Fica restrito a uma reunião no início do ano. A gente não consegue mais dialogar. Eu acho que isso é possível, a gente pode resgatar. Porque é fundamental para entender o aluno que estou recebendo. O Esequiel tem essa sensibilidade porque está próximo ao nosso Departamento. Tanto que, quando eu estava na quarta série com as crianças que eu mencionei anteriormente, eu, meses antes, fui procurar o Esequiel. E o Esequiel se colocou muito receptivo a receber esse aluno. Pensando já na frente como é que ele ia trabalhar com o aluno. Eu acho que a disciplina dele..., porque eu procurei o Esequiel era disciplina que mais exigia o uso das mãos, que o aluno não possuía. Aí me preocupava como é que ele vai ficar em desenho? E ele foi, e fez o colégio sem repetir.

LINCOLN: Ele fez muito bem.

LEILA: Ele fez até o terceiro ano. Na turma em que ele entrou. Então é um vitorioso e nós também. A gente conseguiu, apesar de tudo, dar conta do processo do aluno.

STELLA: Porque é um desafio, e nós temos muito o que aprender. Com os nossos preconceitos, com os nossos padrões.

LINCOLN: Antes se falava de uma cota que era dos servidores, a cota dos professores, e agora nós estamos falhando de uma cota mais universalizada.

JONÊ: E ainda digo mais, Lincoln, numa escola, numa sociedade que ainda não está preparada para receber negros... professores negros. Então, eu, na condição de professora negra, posso dizer isso. E eu posso dizer que é uma escola que não está preparada para nos receber. Como a 
sociedade não está. Então a gente está enfrentando isso, está enfrentando as necessidades especiais, enfrentando as diferenças, a gente está enfrentando. E com o novo. Com um monte de coisas novas.

OLGA: Jonê, será que não vão inventar um projeto, assim que sejam professoras colaboradoras?

JONÊ: Já estou na campanha Olga.

NALU: Mas isso tem, para professores aposentados, que eles podem ter atuação.

JONÊ: Você vem com os projetos, Olga, o espaço para projetos existe para quê? Vamos fazer isso, pensar em projetos!

STELLA: E em somatório às cotas também há a diversidade de bairros. É muito bom. Nós temos agora uma diversidade.

PATRÍCIA: Já tínhamos, agora então...

STELLA: Ainda vamos ter que pensar a Baixada. No projeto de bairros a gente vai ter que pensar a Baixada, enfim.

LINCOLN: Como é que esse seu Departamento, de alguma forma, contribui para essa leitura de mundo?

LEILA: Eles já vão atentos com um olhar para esse mundo lá fora. Então eu acho que, de certa forma, eles também, nas suas perguntas, nos seus espaços que cada professor adiante, trabaIha com ele, e ele chega ao terceiro ano com uma visão critica desse mundo, com uma leitura muito positiva. Eu acho que isso diferencia o nosso aluno.

ESEQUIEL: Você diz que a experiência extramuros, iniciada desde cedo, tem peso nessa formação?

LEILA: Tem. Por exemplo, qual é o nome daquele professor que leva os alunos para Paraty?

LINCOLN: É o de Geografia, Fabio Tadeu.

LEILA: Ele veio me procurar ano passado "Ah queria te conhecer melhor, porque eu cheguei em Paraty com as crianças, com os alunos, e alguns deles me deram até aula. Eles sabiam tudo de Paraty. E aí teve uma hora que eu perguntei como vocês sabem isso tudo?" "Ah, porque a gente viu no primeiro segmento". Então, é a importância de estar com esse olhar. Que eu digo muito, a gente precisa no primeiro segmento alfabetizar o olhar deles. E isso contribui muito para esse olhar de mundo. Então, quando a gente alfabetiza esse olhar ele está aberto até para 
caminhar sozinho. A gente fala assim: "Eles têm preocupação quando eu faço o roteiro pelo Rio Comprido das marcas do século XIX presentes". As mães dizem que eles ficam com essa preocupação. Eles vão para casa e dizem que aquele prédio deve ser do século XIX. Então isso vai ajudando a ler esse mundo de alguma forma. Ler a questão da violência. A gente trabalha tudo com o atual. Trabalhar o jornal, como a gente trabalha no primeiro segmento, é importantíssimo. A gente está discutindo violência, discutindo preconceito. Quando se começou a discussão das cotas a gente vai discutir as cotas... Então eu acho que se você fundamenta no primeiro segmento eles não perdem isso. Vai para toda vida. Eu acho que o trabalho de leitura no primeiro segmento é a nossa grande vitória. Eu acho que contribui muito para formação desse aluno.

LINCOLN: É bom ter esses momentos, ver esses momentos de 1977 onde era um funil, mudou até um pouco o funil com questão do sorteio. O sorteio também deu uma "outra cor". Mas a escola ainda era restrita. $E$ hoje, mesmo que você tenha um exame e entrada no sexto ano, ele já tem uma reserva de vagas. Já é diferente. Já tem um impacto para além do DEF. E tem duas questões que me vieram à cabeça, diria até que são três: primeiro, este Departamento, por mais que você tenha falado do José Gondra, ele é um território de mulheres. Diferente dos outros Departamentos. Como é isso? É diferente em relação aos demais Departamentos, embora o território da educação seja muito marcado pelo campo feminino. Mas como é isso?

OLGA: Ah é um falatório...

JONÊ: É genericamente, melhor, é marcadamente generificado. É gênero. Então assim...

PATRÍCIA: Então nele vêm todas as boas e as más, porque é questão de gênero.

JONÊ: Hoje ainda tem o Fernando (secretário do DEF), ele chega e está a sala gelada feito... e aí a gente fala, e ele vai lá e se dá conta e diminui o ar condicionado.

NALU: Alguém consegue ficar em silêncio...

OLGA: Hora de silêncio não existe.

JONÊ: O legal de o Departamento ser marcadamente feminino é que a gente tem consciência disso. Ninguém ali nega que... a gente põe isso na mesa, a gente sabe que algumas questões estão perpassadas.

OLGA: Por que os homens não querem estar ali? Nós não temos nada contra.

JONÊ: A gente leva isso de modo consciente, a gente brinca quando é para brincar, a gente vai até fazer uma cota agora para homem, né? Para macho sim senhor. Mas a gente sabe da marca 
feminina deste Departamento. E quando a gente olha para essa marca, é a marca do magistério. E a gente não deixa essa...

STELLA: Principalmente nos anos iniciais.

JONÊ: E a gente não deixa essa marca ir para o lado da maternidade. Aí que a gente não aceita o "tia", é que a gente não aceita o pieguismo.

OLGA: Já fizemos questão de falar isso.

JONÊ: A gente faz uma marca mesmo de professoras. Somos professoras, profissionais e tornamos isso cada vez mais um processo consciente.

NALU: O que eu queria tocar é, porque eu fico aqui meio que na dupla função, porque eu deixo o Lincoln perguntar, porque eu acabo sendo parte de vocês, parte do DEF, parte do processo dialético. Mas o que eu acho que é uma coisa importante abordar numa entrevista como essa, eu acho que este Departamento, talvez esta escola, em geral, e ainda mais forte ainda, neste Departamento, pelas características, tem algo muito importante no processo de formação de professor de colaboração, nesse papel de formadores de colaboradores, processo de formação continuada, porque eu acho que faz uma diferença gigantesca, todas nós aqui sabemos que quando você é o professor que... Você é o mestre, é o doutor, o fulano de tal da Universidade, mas você tem... está dando aula para criança. O quanto que isso muda a audiência, quando a gente está dando palestra ou cursos. Isso para mim é uma coisa tão forte, que é uma característica muito peculiar, e eu acho que realmente eu acredito que eu acho, que eu trato isso no meu mestrado, que existe um conhecimento que ele demanda da ação, e que esse conhecimento muito específico está extremamente muito atrelado à ação. E nessa teoria toda de relação com a prática, com essa dialética, mas que o professor, quando você vem com esta marca, ele também te ouve de uma maneira, uma respeitabilidade diferente, porque de alguma maneira, a gente quebra com essa história de que você é o teórico, da teoria e prática para a nossa própria ação. Aí eu penso assim, de vocês tocarem um pouco nisso. Por exemplo, para mim essa criação da pós-graduação e do mestrado, para mim só tem sentido, e eu acho que é um ganho nesse sentido, de que a gente pode, neste momento, estar na sala de aula de criancinhas e ser o professor do mestrado. Então isso, se já era forte antes, então isso vai tornar uma força muito maior. Então eu acho que tem isso, da gente não perder essa perspectiva e eu queria que vocês falassem um pouco disso, como isso acontece, a gente está neste novo momento. 
LINCOLN: Uma das primeiras doutoras eu acho que é do Departamento de vocês, é a Angélica não é? Foi uma das primeiras doutoras do CAp

LEILA: A primeira doutora do CAp.

LINCOLN: As meninas citaram isso. Porque é importante no ponto de vista de quebrar um paradigma, né? De que nos anos iniciais não precisa ter doutorado. Como é que vocês viram isso hein? Essa coisa... eu acho que você vivenciou isso nessa fala, né "Nos anos iniciais precisa de doutorado?" Como vocês conversaram...

JONÊ: Eu acho que o mestrado marca isso. A gente tem um mestrado, hoje, que é único entre os CAps. É o único do Brasil inteiro que tem um mestrado em ensino da Educação Básica. Essa é nossa marca diferencial. Não é mestrado em Educação. É um mestrado em ensino. E o nosso público, nosso alunado hoje, de 20 participantes dessa turma, eles estão na sala de aula. E eles ouvem, assistem a nossa aula ontem éramos eu e Cláudia Cristina, dando aula em uma das disciplinas de Alfabetização e Linguagem e eles ficam assim, ouvindo o que a gente fala com a prática que a gente realiza. Trago os teóricos, mas de manhã eu dei aula para os pequenininhos e de tarde estou dando aula para os grandes.

OLGA: Tem homens nessa turma? Quantos?

JONÊ: Tem. Na minha disciplina tem um homem. Então eu acho que essa marca do mestrado e quando a gente chega e sai do mestrado, com conceito quatro, o primeiro dos mestrados de ensino com o conceito quatro, quatro parece pouco, mas os mestrados iniciam com três, então, assim, é um mestrado que está ganhando muito espaço, dentro da própria unidade. A UERJ reconhece esse nosso mestrado, louva, incentiva. Então, assim, o CAp está sendo olhado. O CAp, que se renova também por esse mestrado. Então eu acho que isso é uma diferença. $O$ nosso Departamento é um Departamento que tem grande participação desse mestrado. A nossa linha de pesquisa, que é linha um e dois, a nossa é linha um.

NALU: É no ensino fundamental, não é isso?

JONÊ: A gente tem uma linha que é do primeiro ao quinto.

NALU: Que o mestrado se compõe assim: um é basicamente anos iniciais, o outro já é para os anos finais.

ESEQUIEL: É foi bom você tocar nesse ponto porque a gente começa a fazer um novo movimento com o mestrado, os grupos de pesquisa são interdepartamentais. Esse resgate pode 
não ser da forma como era, mas há integração... Existe um caminho possível. E esse seu depoimento é muito importante, quando vocês alertam isso, quando vocês chamam para...

JONÊ: Então, assim, é um mestrado que vem fazendo a primeira turma no DEF. O DEF chegou lá, a Cláudia Barreiros que é do DEF, como coordenadora do mestrado. Uma professora dos anos iniciais, que coordena um mestrado. Não é um professor do ensino médio. Não é nessa hierarquia que a escola põe. Ela, junto com o Esequiel, né? Nosso professor de Desenho. Então, assim, tem uma coordenação que vem do DEF, tem uma equipe grande do DEF. Eu acho que a gente tem um chão novo disso que você falou, de ampliar a não cisão entre teoria e prática.

LINCOLN: E é onde teve mais procura, inclusive de candidatos. Maior procura de candidatos foi para projetos com foco nos anos iniciais. Isso demarca objetivamente a importância social disso, tem uma busca social muito grande. Uma demanda social importante.

PATRÍCIA: Eu acho que existe uma outra característica deste Departamento, que, para mim, marca muito e que aí aproveita mais responsabilidades, que para além da sala de aula, o quanto as pessoas que participam deste Departamento gestam a escola. Eu não sei dizer de uma ou outra que em algum momento não participou, ou ainda não participa dessa gestão. Sempre é um Departamento, eu falo que a gestão não é o espaço que mais me agrada, falo isso para o meu diretor constantemente, desde quando ele assumiu a gestão e criou uma coordenação de inclusão dentro do NAPE, que é o Núcleo Pedagógico. Não é o espaço que mais me agrada, mas eu vejo um envolvimento tal qual desse Departamento com essa gestão da escola, que é quase assim: como dizer que não vai ajudar? Como você não vai compartilhar o que você pode, se você vive nesse espaço todo dia? Então eu acho que essa é uma marca deste Departamento também.

LINCOLN: É um Departamento que nunca abriu mão de participar dos projetos de gestão. Mesmo não necessariamente estando nos cargos. Isso é interessante.

NALU: Vocês não iam comentar? Stella? Sobre essa coisa de formação dos professores...? Não? LINCOLN: O que passou pela cabecinha de Stella agora? Que a Stella calou..., respirou fundo... STELLA: Tem coisa passando. É que eu acho... Nós nos silenciamos. Primeiro, nós três falamos à beça. Aí elas começaram a falar, e nós nos calamos num determinado momento. E aí eu, agora, eu estava pensando sobre o nosso silêncio. E pensando assim que esse espaço quando começa, eu fiz parte do ultimo concurso que exigiu mestrado. Embora eu tenha feito mestrado... 
eu fiz depois... Que não exigia. Fiz parte do ultimo concurso que não exigia...

PATRÍCIA: Eu fiz parte do ultimo que exigia só mestrado...

STELLA: E aí, as nossas, às vezes, as nossas resistências, preocupações. Muitas vezes, eu me peguei pensando, várias vezes, e acho que já até manifestei isso publicamente, porque eu sou de expressar. Assim, se nós não nos tornamos, no caso eu e Olga, naquela época, as nossas colegas, com quem nós tínhamos, vocês principalmente, eu já ficava mais silenciada, os embates, porque eu muitas vezes me peguei assim, me considerando uma pessoa resistente a essa dinâmica nova.

LINCOLN: A essa outra exigência.

JONÊ: Esse novo desenho... uma nova frente.

STELLA: Essa nova postura. Uma coisa que eu acho muito importante, aqui no colégio, que não era só o viés político que me atraiu, mas principalmente a formação de postura. Então eu acho que o CAp se tornou um espaço de formação para mim, na medida em que eu não me transformei apenas numa melhor professora alfabetizadora, mas sim em uma professora em todos os aspectos. Por exemplo, aqui aprendi que 7 horas são 7 horas, com a Dirce.

NALU: A Dirce realmente, ela fala: "são dez para as sete...".

STELLA: Não só com a Dirce. Mas, eu aprendi que sete horas é na sala de aula.

OLGA: É o nosso horário.

STELLA: Não só com a Dirce. Nós ficávamos conversando, mas quando dava cinco para as sete, ninguém precisava falar com ninguém. Todo mundo já pegava a bolsa e subia. Então eu aprendi aqui tantas coisas, que eu ficaria aqui falando.

OLGA: Regras de responsabilidade.

STELLA: E a formação dessa postura profissional, a se ver de outro modo, a se ver de forma respeitosa, enquanto, né, eu lia Paulo Freire, mas na prática, quando eu vi o tratamento, muitas vezes que nós tínhamos com o município, nos nossos espaços no município, eu sempre, quando chego aqui, eu vejo essa possibilidade. E agora, ouvindo as colegas falando, eu parei para pensar nisso. Quanta coisa eu aprendi, quanta coisa tenho para aprender e aprendo sempre. Com todo mundo é claro, é óbvio, com as mudanças inclusive, mas o quanto a gente ainda tem resistência em relação ao que é novo. As nossas dificuldades de lidar, assim, na prática, com o que é novo. Por exemplo, um mestrado, eu me preocupo, tem um viés do ensino, que eu acho fun- 
damental, mas também tem o ensino daqui, então, sei lá, às vezes isso cria um movimento.

JONÊ: Um mal estar...

STELLA: Um esvaziamento no nosso ensino.

LINCOLN: Uma dúvida.

STELLA: E isso me traz muitas questões, eu não poderia deixar de falar, porque eu costumo explicitar muito os meus sentimentos e as minhas reflexões, eu acho que é importante isso.

JONÊ: Isso é um conflito que a gente está vivendo aqui nesne momento Stella. Foi o que eu falei para o Lincoln, é uma escola de conflito.

STELLA: Você lembra da sala Revoluti? Que eu me contrapus e chegou um determinado momento eu voltei atrás e falei não, eu não posso impedir que vocês, que amam tecnologia, né? Que são dessa geração, eu não posso votar contra algo, que neste momento não pertence ao meu interesse, não é do meu interesse, mas seria. Eu cheguei a comparar, como se nós estivéssemos, assim, criando impossibilidades para o como se aprende. Que as crianças chegavam no segundo ano, mas não escreviam corretamente, mas elas tinham, elas eram valorizadas no sentido da apropriação do conhecimento, da reflexão do conhecimento. Nós estávamos levando em consideração o processo do aluno. Então eu me coloquei em vários momentos aqui, voltando se eu não seria aquele grupo que resistiu naquela época.

PATRÍCIA: Isso foi quando vocês montaram um curso e depois foram para vários municípios, porque também era o novo. É outra função de como hoje é a outra parte dessa função docente, que é o mestrado.

JONÊ: Existe sempre um desafio novo.

OLGA: É a resistência ao novo, né?

JONÊ: Aí eu trago a Sonia, né? Não dá para jogar o bebê e a água do banho fora, né? Não é à toa que eu ainda fico embasbacada de ter ouvido, já estou aqui há onze anos. Quantas vezes eu já ouvi Olga? E toda vez que eu escuto eu me emociono... É porque é isso, eu preciso dessa tradição.

STELLA: E agora eu, ouvindo vocês, que aqui no meu silêncio eu ouvindo, o quanto a gente percebe e que sente também, qual foi mesmo o adjetivo que você usou em relação à Olga mesmo? Que você fica emocionada... Embasbacada... E quando eu ouço vocês falando dos novos projetos assim, com a empolgação que vocês têm, eu também fico embasbacada... 
OLGA: É o novo, né? A resistência ao novo vai deixando de ser tão novo e a gente vai vendo como é bom...

JONÊ: E outros, quando chegarem, eu vou ser a velha... Eu só tenho onze anos no CAp.

NALU: Eu estava com essa sensação de que vou ficar velha também... Agora Patrícia, eu sempre acho que ela é novinha...(risos)

LINCOLN: Qual a sensação, Alice, escutando isso tudo, essas meninas...?

ALICE: Puxa vida! A sensação é de que você... Olha a gente acha que fez tão pouco, né? Quando a gente se lembra, quando a gente se aposenta, a gente acha assim, tudo que você fez, que você lutou, puxa vida, quando eu penso que a gente aqui pode recordar tanta coisa! E podemos assim recordar muita coisa, passa um filme antigo, né? Aí você vê que têm pessoas que estão continuando lá, lógico, com as suas características, outras lutas e outros momentos, mas que estão vestindo a camisa, que estão nessas lutas todas e estão conseguindo também fazer muita coisa boa. Enfrentando desafios, claro, porque educação sem desafio não existe. $\mathrm{E}$ aí, assim, é muito bom ouvir isso.

OLGA: Dá saudade...

ALICE: Dá sim e, é aquela coisa da aprendizagem.

STELLA: Uma saudade gostosa...

ALICE: Uma saudade gostosa...

JONÊ: E dá prazer nesta tarde, né? Obrigada à e-Mosaicos.

ALICE: Eu parei de trabalhar, na verdade, em 2011. Foi meu último trabalho que eu fiz, né? Não trabalho atualmente, porque meu trabalho é ser avó.

NALU: E quando a Alice se aposentou, ela se aposentou no segundo semestre e eu segui com a turma dela. Eu dividia e acabei pegando a turma inteira. Porque não era uma regra ter duas professoras, mas eu dividia com ela e acabei ficando com a turma toda, foi muito bacana...

STELLA: É muita responsabilidade.

NALU: Mas eu acho que é isso. Nós queríamos agradecer muito a vocês. Especialmente pelo dia de hoje. Nós sabemos aqui, o quanto seria complicado vocês terem vindo. Agradecer muito a Alice que é aposentada, mais distante disso tudo, e se disponibilizou a estar aqui conosco. Muito obrigada! Espero que a gente consiga fazer um bom trabalho aqui de organização deste texto para e-Mosaicos. E vocês verão isso no site. 
OLGA: E foi muito bom a gente lembrar, fazer voltar nessas memórias. É emocionante.

JONÊ: Constituiu, né? Eu me vi emocionada aqui várias vezes. Gostei muito.

NALU: Faltam, na prática, esses momentos. Eu acho que esses momentos estabelecem laços que faltam. São elos que faltam.

JONÊ: Eles fazem a costura que nós temos feito.

OLGA: Lembramos de outras pessoas.

NALU: Isso nos ajuda, se a gente tivesse isso, nós teríamos menos conflitos.

JONÊ: Acho que o DEF ia gostar de ver, de se ouvir. O DEF. Aquele masculino (risos): o DEF.

ALICE: As outras pessoas antigas como eu, né? Andrea, no tempo de ouvir.

OLGA: Cristina, que está em curso. E Dirce, que está em curso.

NALU: Inclusive porque traz o outro grupo, Dirce, talvez, se depois, nós pudéssemos buscar Solange, Vania, essas pessoas que são outro grupo. Mas eu estou olhando aqui e não estou vendo ninguém do grupo de quando eu cheguei. Tinha um grupo, todo mundo muito sério, competente, muito responsável, mas era muito, assim, visível. Eram dois blocos, nessa linha, da entrada da Emilia e o outro super tradicional... e quando a gente olha...

STELLA: Mas eram os que organizavam muito bem o trabalho.

NALU: Mas foi o que eu falei, era um trabalho extremamente competente. Mas a discussão e concepção, hoje a gente olha e acha super bacana, mas na hora a gente ficava arrancando os cabelos. Mas o quanto isso era rico.

JONÊ: O quanto isso é escola.

LINCOLN: Milton Santos é que diz que "o verdadeiro intelectual é aquele que dá conta do seu tempo". Então, na verdade, essas pessoas deram conta do seu tempo. E isso faz com que nós tenhamos a responsabilidade. Acho que é um pouco do que Patrícia, do que Jonê estavam falando, você (Nalu) agora nessa última fala também. Nós estamos tentando dar conta do nosso tempo, e outros virão, lerão estes registros e, espero, tomarão consciência para dar conta daqui para frente.

OLGA: Eu queria terminar assim, lembrando que nós não havíamos falado da Cidinha, Cidinha para os íntimos, a Maria Aparecida Ferreira, mas que foi parte integrante desse grupo também, dessa luta da alfabetização. Professora apaixonada até hoje. Falamos muito pouco, queria dizer o nome dela. Não esquecemos dela, também, como parte fundamental. Tivemos muitas discus- 
sões, muito trabalho em conjunto, foi uma época muito feliz.

NALU: A Cidinha é uma professora fantástica. Segurou cada uma. Teve duas crianças na mesma turma. E ela que me deu a belíssima notícia de que eu tinha passado no concurso do CAp. Porque eu morava longe, aí a Cidinha que ligou e falou: "Olha, você passou!" Eu pensei que o resultado era no outro dia... Aí, lembrei da Cidinha "Ah parabéns..." "Parabéns de quê?"

ALICE: Agora, fora elas, tinha a Leila e a Dirce, que não eram tão no embate. Que não entravam tanto no embate. A Dirce reconhecia algumas coisas do trabalho, até porque ela começou a trabalhar nas primeiras séries, então ela viu como se era dado, foi bem interessante.

NALU: A Dirce ficava no meio termo...

ALICE: E a Leila, para mim, que foi a pessoa com quem eu mais aprendi muito, porque ela era uma pessoa assim de vanguarda. Foi professora três anos das nossas filhas, ela, eu achava ela uma pessoa...

OLGA: Uma "ídala".

STELLA: Uma educadora, né? O trabalho.

ALICE: Nossa, para mim ela teve um trabalho.

LINCOLN: Afinal, nós não falamos sobre uma coisa.

OLGA: Por exemplo, a Fundação do Clube de Leitura.

LEILA: O Departamento foi incorporando algumas ideias novas, que não era só eu que propunha coisas novas. E essa turma foi muito engraçada, por isso é uma turma muito especial, eu tinha filhos de professores do DEF. A filha da Olga era dessa turma... A Olga sempre foi uma pessoa que me deu muito... A Olga era mãe representante, ainda não era professora da escola. Era mãe representante dessa turma. E ela sempre comprou as ideias. Ela fazia as cabeças das mães... "Não, isso aí é uma inovação, vai dar certo". Com o clube, então, a Olga foi uma pessoa que me deu muita força. Mas tinha a Alice, que no início a Alice... Só depois quando ela foi para o grupo de psicopedagogia, começou a comprar as ideias. Mas ela criticava muito... O trabalho de correção de texto, por exemplo. Eu não tenho direito de ser coautor deles. Então eu já fazia um trabalho de correção que era extremamente criticado. Que depois o grupo de alfabetização veio comprar. O erro construtivo. Eu não tinha noção teórica não, tinha uma coisa empírica. Não tinha. Eu comecei a ler sobre esses assuntos depois, no grupo, mas eu achava que era um caminho. E como não tinha nenhuma teoria me embasando era não saber o que fazer com as 
crianças. Aí tanto que tem um depoimento da Alice e da Olga falando isso. Eu tenho esse depoimento. Eu guardo, com muito carinho, um depoimento escrito numa reunião de pais. Mas era difícil. Até as pessoas irem comprando as ideias, a gente tinha pessoas que eram de uma linha muito tradicional. Aí quando eu passava os trabalhos de casa, aí... Na época da construção do metro, com essa turma, vocês vão entrevistar as pessoas, as lojas... Qual é a visão hoje...

LINCOLN: $O$ espírito da expedição.

LEILA: É... a semente da expedição. Como eu tive mãe atrás de mim... "A gente tem o que fazer". Mas, gente, é importante eles terem esse contato com as pessoas.

ESEQUIEL: É muito interessante que algumas coisas entraram um pouco nas relações, nas iniciativas, entraram para o calendário acadêmico pedagógico. E outras não. Outras continuaram como ações isoladas e outras se perderam mesmo. Paraty por exemplo, é uma...

LEILA: Paraty, o Café Literário... Que é tudo que nasceu no clube. Os roteiros todos ...o que eu fazia para estudar bairro, tem que conhecer o bairro, tem que ir para a rua. Então hoje está incorporado na dinâmica do Departamento. É o bairro, andando pelo Rio Comprido, é o Circuito Ludi, tudo do Clube. Que surgiu daí: o Circuito Ludi e Paraty, que são grandes atividades do primeiro segmento.

LINCOLN: A própria influência na festa junina. Tem uma influência na festa junina temática, né?

LEILA: A festa junina, porque o grosso é esse trabalho em conjunto da Educação Física com Música, com primeiro segmento, a festa junina é o maior exemplo. A gente faz um trabalho junto. É o primeiro segmento elaborando convite... Então acaba o primeiro segmento muito mais atuante na festa... as danças todas... É um trabalho coletivo de Artes, Música, Educação Física, tanto que a gente... o último ensaio da festa é a tarde inteira, todo mundo junto... trabalhando as danças... Então é um trabalho que dá certo. É uma pena que isso não aconteça nos outros segmentos. Um momento que vocês devem ter pego na época, era da Feira Comunitária. A Feira Comunitária foi uma pena se perder. Era um trabalho que envolvia o morro do Turano, que nós estávamos ali dentro e é um trabalho muito importante... de fazer exame no pessoal...

LINCOLN: Para gente destrinchar, por exemplo, as relações que vocês passaram a ter com a mulher do DEF: o DEFA. Mônica é que diz que o DEF é o marido da DEFA. Estes também foram 
entrando na relação, nessa formação dos anos iniciais. Então dava para puxar vários outros novelos.

NALU: Esquecemos disso. Mas vai ter que ser para um outro momento por causa da hora. $\mathrm{O}$ pessoal da Fono, quando tinha aquele Departamento. Que eles entravam na sala e levavam, a gente dividia a turma, era um momento em que a gente podia ficar com a metade da turma e fazendo trabalho. E elas faziam uns trabalhos super sérios, respeitáveis. A gente tinha isso, a possibilidade de ficar com a metade da turma, porque eles pegavam a outra metade para fazer esse outro trabalho. E era um Departamento. Era um Departamento? Eu não sei.

LINCOLN: Setor de fono, psicopedagógico.

NALU: Era uma equipe. Que elas tinham um trabalho, talvez, que chegasse próximo de você, sendo o que você faz, Patrícia, hoje, num outro contexto. Seria esse grupo que a gente acabou esquecendo disso. Mas acho que seria uma boa...

LINCOLN: Sim, sim.

NALU: Importante recuperar isso. De uma relação muito forte dentro do DEF. Elas faziam o trabalho com a criança.

LINCOLN: Quero registrar agora um agradecimento que a gente faz a essa equipe aí de apoio, que foi fundamental, Carol, Leonardo, Atílio... a coordenadora que se eu não falar dela, ela "despede" a gente (Lincoln, Nalu e Esequiel), que é a professora Andrea, que está ali quietinha, mas que já sabe que vai ter muito trabalho para repensar essa transcrição. E eu queria fazer um elogio muito legal a essa menina aqui da extensão. Que tem tocado a barra aí com a gente, que não tem sido fácil. É mais um dos membros desse DEF que não se furta a participar dos projetos maiores da Instituição.

OLGA: O DEF é um polvo.

JONÊ: O DEF é uma "polva" (risos).

LINCOLN: Eu posso dizer que a gestão não existiria, eu falo isso para a Andrea, que essa gestão não existiria se não fosse o DEF. E acho que, na verdade, a Unidade passou a existir, de uma outra forma, a partir de 1977. Embora eu não estivesse aqui, mas tudo o que eu escuto falar da instituição pré 77 tem uma cara bastante diferente da instituição pós 77.

OLGA: Porque ali o 7 é cabalístico, né? Que foi em 1957 foi quando foi criado o Colégio de Aplicação, em 1977 o Departamento, em 1987 a mudança de postura, a criação da C. A. Então o 7 
é bem..

LINCOLN: Mas é sim. 98 nós viemos para cá, na verdade em 98 que nós viemos para cá. Mas a construção foi em 97. Mas o processo todo de mudança foi em 97.

JONÊ: Então vamos esperar 2017 (risos).

NALU: Mas eu acho a sugestão da Jonê interessante.

LINCOLN: A gente faz 50 anos em 2007, que aí tem o encontro de todos os CAps. O maior encontro de todos os CAps foi aqui.

JONÊ: Seria legal fazer uma entrevista com os diretores vivos.

NALU: Essa ideia da Jonê é boa para o livro de memória.

ANDREA: Em falar em livro de memória nós estamos fazendo para os 60 anos do CAp.

OLGA: Trouxemos um livro de memória das professoras de Mesquita, que todo ano começávamos o projeto, começávamos o curso ouvindo as histórias delas, como alunas, como foi o seu processo, como foi o processo de alfabetização delas. Ouvimos no primeiro encontro e depois elas escreviam. A cada ano nós temos um livro. Que esse aqui eu vou dar de presente para a Fátima, nós vamos dar, porque foi de Mesquita, onde nós ficamos 6 anos, participando junto com a Fátima que era Secretária de Educação. Então trouxemos isso. Tinha convite para começar o curso, olha que legal! Tinha mesa com o prefeito, com a secretaria de educação. Era um evento no município. Sabe, um evento muito concorrido. E uma briga, porque nós só tínhamos 30 vagas e muito mais professoras queriam participar.

PATRÍCIA: É uma identidade, né?

LINCOLN: Quer falar, professora Andrea?

ANDREA: Acho que preciso, né? Eu acho que agradecer Nalu e Lincoln por terem topado o desafio, quando a gente discutiu a pauta das sessões da e-Mosaicos. Então, a ideia é que a gente possa estar ouvindo esta Instituição pelas vozes dos diferentes atores que fazem as suas histórias, do ponto de vista do trabalho. E pensando um pouco no viés do trabalho docente, o tempo todo vocês trazem como é o trabalho aqui dentro do Instituto de Aplicação. Acho que não dá para não dizer que foi um momento para mim, apesar de eu não ter participado, a todo momento, aqui hoje, de uma grande escuta, de um grande aprendizado. Mais um. Acho que, desde que eu cheguei aqui, em 2003, junto com a Jonê, a gente vem aprendendo, vem aprendendo nas aproximações, vem aprendendo nos conflitos, vem aprendendo nas novidades que 
surgem, na resistência ao novo, nessa caminhada. Porque é isso. É assim que a gente aprende, assim que a gente aprende com os nossos alunos e os ensina a aprender também. Acho que é uma via de mão dupla, o tempo todo. Gostaria de agradecer. A ideia é que cada um desses vídeos componha o acervo de memória que a gente está fazendo no NEPE. É justamente o exercício de dar uma cara para a memória para fora, para além do grande trabalho que a Leila, não sei se foi ela que iniciou, mas que ela tocou por muitos anos aqui, que é repensar a recuperação da memória institucional. Então, desde 2012, a gente tem trabalhado muito nesse sentido. A memória hoje já tem sua sala, reconquistada nesta gestão. Estamos fazendo as pesquisas, os levantamentos de atas para localizar em que Conselho Departamental foi aprovado o nome do Centro de Memória. O registro que a Leila traz é Centro de Memória Fernando Sgarbi Lima. A gente está tentando localizar se isto está em ata ou não. Se não, vai se submeter à aprovação do Conselho, para que a placa deixe de ser Centro de Memória do CAp-UERJ para ser Centro de Memória com o seu nome. Então, eu gostaria de agradecer muito. A gente vai fazer como a Nalu falou, um esforço para a transcrição e a organização das falas deste grupo, com o outro grupo. É um grande desafio. Mas, para além disso, gostei muito da sugestão, não lembro quem falou, de que a gente passe esse vídeo para o DEF. Agora é o tempo de editar, juntando os dois grupos numa edição única. Bem, isso tudo vale uma tarde.

OLGA: Viver a beleza e ser um eterno aprendiz.

ANDREA: E como precisamos, né?

OLGA: Eu acho que é isso que a gente vive.

ANDREA: Vive e precisa continuar vivendo. 